\title{
Developing a Neuronal Model for the Pathophysiology of Schizophrenia Based on the Nature of Electrophysiological Actions of Dopamine in the Prefrontal Cortex
}

\author{
Charles R. Yang, Ph.D., Jeremy K. Seamans, Ph.D., and Natalia Gorelova, Ph.D.
}

This review covers some recent findings of the electrophysiological mechanisms through which mesocortical dopamine modulates prefrontal cortical neurons. Dopamine has been shown to modulate several ionic conductances located along the soma-dendritic axis of prefrontal cortical pyramidal neurons. These ionic currents include high-voltage-activated calcium currents and slowly inactivating $\mathrm{Na}^{+}$and $\mathrm{K}^{+}$currents. They contribute actively in processing functionally segregated inputs during synaptic integration. In addition, dopamine mainly depolarizes the fast-spiking subtype of local GABAergic interneurons that connect the pyramidal neurons. This latter action can indirectly control pyramidal cell excitability. These electrophysiological data indicate that the actions of dopamine are neither "excitatory" nor "inhibitory" in pyramidal prefrontal cortex neurons. Rather, the actions of dopamine are dependent on somadendritic loci, timing of the arrival of synaptic inputs, strength of synaptic inputs, as well as the membrane potential range at which the PFC neuron is operating at a given moment. Based on available electrophysiological findings, a neuronal model of the pathophysiology of schizophrenia is presented. This model proposes that episodic hypo- and hyperactivity of the PFC and the associated dysfunctional mesocortical dopamine system (and their interconnected brain regions) may coexist in the same schizophrenic patient in the course of the illness. We hypothesize that the dysfunctional mesocortical dopamine input to the PFC may lead to abnormal modulation of ionic channels distributed in the dendritic-somatic compartments of PFC pyramidal neurons that project to the ventral tegmental area and/or nucleus accumbens. In some schizophrenics, a reduction of mesocortical dopamine to below optimal levels and/or a loss of local GABAergic inputs may result in a dysfunctional integration of extrinsic associative inputs by $\mathrm{Ca}^{2+}$ channel activity in the distal dendrites of PFC pyramidal neurons. This may account for the patients' distractibility caused by their inability to focus only on relevant external inputs. In contrast, in acute stress or psychotic episodes, an associated abnormal elevation of mesocortical dopamine transmission may greatly influence distal dendritic $\mathrm{Ca}^{2+}$ channel-mediated signal-processing mechanisms. This can enhance possible reverberative activity between adjacent interconnected pyramidal neurons via the effects of dopamine on the slowly inactivating $\mathrm{Na}^{+}, \mathrm{K}^{+}$, and soma-dendritic $\mathrm{Ca}^{2+}$ currents. The effects of high levels of PFC dopamine in this case may contribute to behavioral perseveration and stereotypy so that the patients are unable to use new external cues to modify ongoing behaviors. [Neuropsychopharmacology 21:161-194, 1999] (C) 1999 American College of Neuropsychopharmacology. Published by Elsevier Science Inc.
From the Neuroscience Research (CRY), DC 0510, Eli Lilly \& Company, Lilly Corporate Center, Indianapolis, Indiana; Department of Psychology and Psychiatry (CRY, NG), University of British Columbia, Vancouver, BC, Canada; and Computational Neurobiology Lab (JKS), The Salk Institute, La Jolla, California.
Address correspondence to: C. Y. Yang, Ph.D., Eli Lilly and Company, Neuroscience Research, DC 0510, Lilly Corporate Center, Indianapolis, IN 46285.

Received May 12, 1998; revised May 27, 1998; accepted May 29, 1998. 
KEY WORDS: Dopamine; Schizophrenia; Dendrites; $\mathrm{Ca}^{2+}$ Channels; Persistant sodium current; Prefrontal cortex; Nuclues accumbens, GABA interneuron

Schizophrenia strikes one in one hundred people worldwide, regardless of cultural or racial origins. As the illness progresses and if it remains unattended, patients are frequently trapped in psychological, social, and economic devastation (Gottesman 1991; Jablensky 1995). Currently, our incomplete understanding of the neurobiological bases of schizophrenia suggests that defects in the genetic controls of brain development in such limbic regions (including temporal lobe structures such as hippocampus and the amygdala) as well as the prefrontal cortex (PFC) lead to cell loss or deformation, cytoarchitectural disorganization, and abnormal innervation in these brain regions (Roberts and Bruton 1990; Stevens 1992; Bogerts 1993; Shapiro 1993; Akbarian et al. 1993, 1996; Ross and Pearlson 1996; Weinberger 1996; Karayiorgou and Gogos 1997; Lewis 1997; Selemon et al. 1995, 1998).

Some results from recent imaging studies of brains from living schizophrenics have suggested that there are defective functional communications between the interconnected cortical (PFC and cingulate cortex) and limbic subcortical structures (thalamus, striatum, and temporal lobe limbic structures)(see reviews of Liddle 1996; Pfefferbaum and Marsh 1995; Andreasen 1997; Heckers et al. 1998). Findings from these studies suggest that in schizophrenics, abnormal recruitment of several interconnected cortical and subcortical structures may underlie such symptom clusters as psychomotor poverty, thought disorganization, and reality distortion (Liddle et al. 1992; Liddle 1996; Fletcher 1998; Heckers et al. 1998).

As noted in Figure 1, the PFC receives converging limbic, association cortical, and mesocortical dopamine inputs. These inputs interact in the PFC and are involved functionally in high-level cognitive processes (Fuster 1995). Among the many brain regions that PFC output innervates, two important subcortical regions are emphasized in this review. These are the nucleus accumbens (where mesoaccumbens dopamine neurons terminate) and the ventral tegmental area (VTA, where the midbrain dopamine neurons reside) (Sesack et al. 1989; Groenewegen et al. 1990; Berendse et al. 1992a, 1992b; Sesack and Pickel 1992; Gorelova and Yang 1997b). Several of the interconnected limbic, cortical, and subcortical structures known to be affected in schizophrenia are targets of the ascending midbrain dopamine systems that normally provide functional modulation of neurotransmission (Björklund and Lindvall 1984; Mogenson et al. 1993).

Alteration of dopamine transmission in PFC and/or the nucleus accumbens has been hypothesized to be part of the pathophysiology of schizophrenia. Several

\section{Principal limbic circuits that interact with the DA systems}

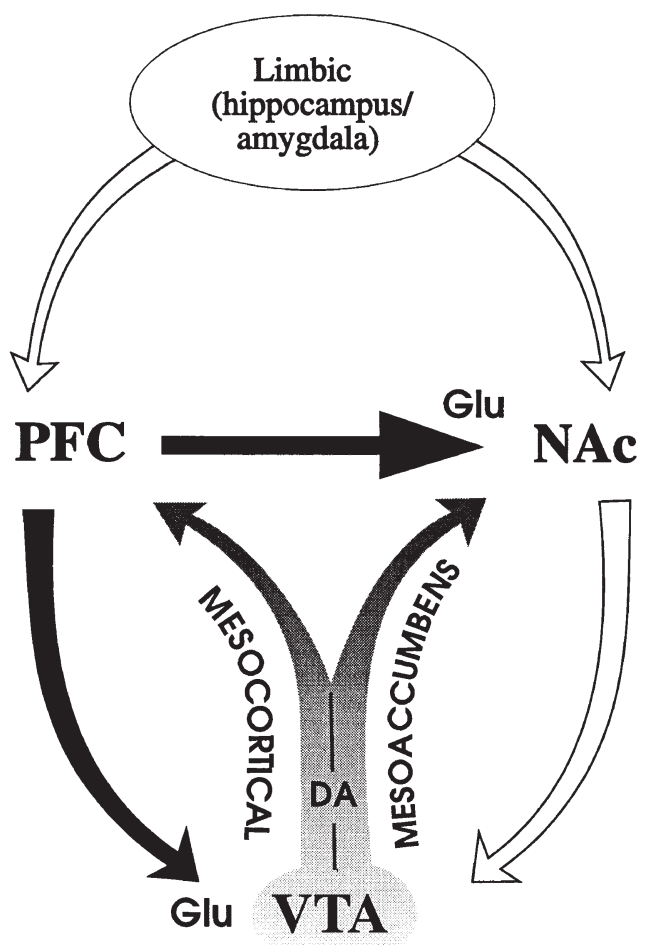

Figure 1. Schematic drawing illustrating the neuroanatomical interrelationship between amygdala, hippocampus PFC and Nac, as well as PFC outputs to the NAc, and the A10 dopamine perikarya in the VTA. These connections provide the potential functional links by which cortical and subcortical dopamine systems may interact.

lines of evidence seem to favor this hypothesis. First, many clinically efficacious antipsychotics are potent dopamine receptor antagonists (Seeman 1992). Second, dopamine receptors (Okubo et al. 1997) or the release dynamics of dopamine terminals (Wong et al. 1997) are markedly altered in living schizophrenic brains. Third, several psychoactive substances (e.g., amphetamine, phencyclidine) abnormally augment dopamine transmission and induce psychotic symptoms indistinguishable from schizophrenia. These lines of evidence have provided the bases for the "Dopamine Hypothesis of Schizophrenia" (Davis et al. 1991; Cohen and ServanSchreiber 1993; Carlson 1995).

Detailed electrophysiological mechanisms that underlie the dynamic actions of neurons (i.e., in the timescale of milliseconds, seconds, to minutes) in interconnected cortical-subcortical network of neurons are currently lacking. This review focuses primarily on the nature of electrophysiological actions of dopamine in the PFC. It is hoped that an understanding of dopaminergic actions on cortical-subcortical interactions may lead to some insights into the mechanisms responsible 
for the dopamine-mediated pathophysiology of schizophrenia. Based on available electrophysiological results, we attempt to provide a neuronal model to account for certain aspects of the pathophysiology of schizophrenia. Although outside the scope of this review, we acknowledge that other neurotransmitter/neuromodulator systems undoubtedly interact with the dopamine systems to contribute to the complex pathophysiology of schizophrenia. Among the neurotransmitter systems implicated are those that use glutamate (Olney and Farber 1995), serotonin (Iqbal and van Praag 1995; Kapur and Remington 1996; Busatto and Kerwin 1997; Marek and Aghajanian 1998), and noradrenaline (Joyce 1993).

\section{Mammallian PFC and the Mesocortical Dopamine Inputs}

Mammalian PFC has been defined anatomically as the cortical region with strong reciprocal innervation with the mediodorsal thalamus (MD)(Uylings and van Eden 1990; Kolb 1984; Groenewegen et al. 1990). Although this criterion remains a topic of debate among neuroanatomists, it has served as a useful starting point for defining the PFC. Using criteria suggested by Campbell and Hodos (1970) to define homology for brain regions between different species (e.g., connections, topography, positions of sulci, embryology, neuronal morphology, histochemistry, electrophysiology, and behavioral changes resulting from lesion and stimulations), Kolb (1984) cautiously proposed that the prelimbic and infralimbic regions of the rodent PFC and dorsolateral PFC in primates are functionally analogous.

The PFC receives a distinct branch of the dopamine inputs originating from the midbrain VTA. A large body of anatomical literature using rodent, primate, or human brains has described this mesocortical dopamine input to the PFC in considerable detail. The rodent PFC receives mesocortical dopamine input from separate populations of $\mathrm{A} 9$ and $\mathrm{A} 10$ dopaminergic neurons located in the substantia nigra and VTA, respectively (Fallon and Moore 1978; Swanson 1982; Björklund and Lindvall 1984). The rodent mesocortical dopamine innervation is mainly confined to the limbic cortices, including the prefrontal, anterior cingulate, insular, piriform, perirhinal, and entorhinal cortices (Björklund and Lindvall 1984; Berger et al. 1991).

Although the sources of mesocortical dopamine in human have not been fully characterized, it has been shown that the primate PFC and anterior cingulate cortex receive mesocortical dopamine inputs from the VTA (Porrino and Goldman-Rakic 1982). Hence, although the midbrain sources of dopamine neurons are quite similar in these three commonly studied species, human and nonhuman primates have a much expanded cortical innervation by dopamine neurons relative to the rodent cortex. This dopamine input provides a much more expanded area of innervation in primate and human cortices, encompassing a widespread area of the sensorimotor and association cortices. In primate and human brain, a substantial amount of tyrosine hydroxylase- or dopamine-immunoreactive fibers are found in the motor, premotor, supplementary motor area, parietal, temporal, and posterior cingulate cortices (sensorimotor), in addition to prefrontal, anterior cingulate, insular, piriform, perirhinal, and entorhinal cortices (association)(Berger et al. 1988; Gaspar et al. 1989; Smiley and Goldman-Rakic 1993).

Within the individual cortical layers in the PFC, the mesocortical inputs exhibit a distinctly different pattern in rodent vs. primate and human. In the rodent PFC, afferents from the VTA region (A10) provide dense dopamine input to the deep layers V-VI. The significantly sparser, but extensively collateralized, dopamine innervation to the superficial layer I-III of the rodent PFC originates in the A9 medial substantial nigra and the lateral A10 regions (Descarries et al. 1987; van Eden et al. 1987; Berger et al. 1991). On the other hand, the primate and human PFC receive dense bilaminar dopamine inputs: one to the deep layers V-VI, and the other to the superficial layers I-II, with the middle layer III receiving comparatively sparse dopamine innervation (Gaspar et al. 1989; Berger et al. 1991; Lewis et al. 1992; Smiley et al. 1992; Williams and Goldman-Rakic 1993; Krimer et al. 1997). Thus, in all species, the deep layers V-VI receive dense dopamine innervation, but the density of dopamine innervation in the superficial layers I-III varies across species.

The most common synaptic target of the dopamine terminals in the PFC of rodent, primate, or human seems to be the dendritic spines and shafts of putative pyramidal neurons (Van Eden et al. 1987; GoldmanRakic et al. 1989; Verney et al. 1990; Smiley et al. 1992; Smiley and Goldman-Rakic 1993; Carr and Sesack 1996). Both tyrosine hydroxylase- or dopamine-immunoreactive axonal terminals have been found to form symmetric synapses on the spines and shafts of small diameter distal dendrites derived from pyramidal neurons. Many of the postsynaptic spines innervated by dopamine terminals also receive unlabeled asymmetric (putative excitatory) terminals. Thus, a "triadic" synaptic arrangement is formed. This synaptic "triad" may form the neural substrate whereby pre- and postsynaptic dopamine modulation of the excitatory afferents to the pyramidal cell occurs (van Eden et al. 1987; Séguéla et al. 1988; Goldman-Rakic et al. 1989; Verney et al. 1990; Smiley et al. 1992; Goldman-Rakic 1992; Smiley and Goldman-Rakic 1993; Carr and Sesack 1996).

\section{Multiple Forms of Dopamine Receptors in the PFC}

Molecular biological techniques have enabled the identification and characterization of several genes that encode at least five different brain dopamine receptors. 
These findings have led to a revision of the traditional classification of dopamine receptors D1 and D2 subtypes based simply on their positive (D1) or negative (D2) association with the G-protein-coupled adenylate cyclase system (Niznik and van Tol 1992; Ogawa 1995). On the bases of their primary structure, chromosomal location, mRNA size, and biochemical and pharmacological differences, a D5 receptor is now attributed to be a second member of the D1 receptor subfamily, and the D3 and D4 receptors are classified as members of the D2 receptor family (Sunahara et al. 1991; Seeman 1992; Niznik and van Tol 1992; Ogawa 1995).

To enhance the specifity in the detection of dopamine receptor subtypes, in situ hybridization of dopamine receptor mRNAs, or combined dopamine receptor immunocytochemistry and dopamine receptor binding autoradiography, have been used. Whether the receptor mRNAs detected represent those that will be completely translated into functional receptor proteins is unknown at present. Only studies that show some details of the distribution of mRNA for the dopamine receptor subtype and their corresponding binding sites in the frontal or prefrontal cortex are reviewed selectively below.

In rodent frontal or prefrontal cortices, there is a moderate level of expression of mRNA for D1 in deep layer V-VI (Mengod et al. 1991; Fremeau et al. 1991; Mansour et al. 1991; Huang et al. 1992; Gaspar et al. 1995). A comparatively lower expression of $D 2$ receptor mRNA is distributed in superficial layers I-III (Mansour et al. 1990; Bouthenet et al. 1991) as well as in deep layer V (Gaspar et al. 1995). Findings from doublelabeling studies using the retrograde axonal tracer Fluorogold combined with in situ hybridization of D1 and D2 receptor mRNAs, have shown further that many of the deep layer V-VI PFC neurons possessing D1 and D2 receptor mRNA are corticocortical, corticothalamic, and corticostriatal neurons (Gaspar et al. 1995). Thus, modulation of these PFC output neurons via D1 or D2 receptor activation can influence cortical and subcortical neurotransmission in rodent. In general, most of the D1 and D2 receptor mRNAs in rodent PFC are present in the deep layers V-VI, with much lighter labeling in the superficial layers (Mansour et al. 1990, 1991; Huang et al. 1992; Vincent et al. 1993, 1995).

With the current lack of selective ligands for dopamine D3, D4, and D5 receptors, brain distribution of these subtypes has been determined primarily by in situ hybridization of mRNA for these receptors. Dissimilar to the distribution of D1 and D2 receptor mRNA reviewed above, only very low levels of D3 (Sokoloff et al. 1990; Bouthenet et al. 1991), D4 (van Tol et al. 1991; Ariano et al. 1997), and D5 (Sunahara et al. 1991; Laurier et al. 1994) receptor mRNAs have been found in the rodent frontal cortex samples (which included the region of the PFC). However, using antisera raised against the D4 receptor protein, intense immunoreactive staining was found in pyramidal neurons of the frontal cortex throughout deeper layers III-VI. In addition, smaller putative interneurons were also stained occasionally (Ariano et al. 1997). This mismatch of mRNA and binding sites may reflect our lack of understanding of the degree of efficiency of translation of receptor mRNA to functional dopamine receptor proteins.

In primate $\mathrm{PFC}$, pyramidal neurons immunoreactive to D1 and D5 receptor proteins were found in superficial layers II-III and deep layers V-VI, with layer V neurons showing clearly stronger expression of D4 and D5 receptor mRNAs (Lidow et al. 1991, 1998). This pattern matches their receptor binding sites and the corresponding bilaminar mesocortical dopamine inputs (Goldman-Rakic et al. 1990; Lidow et al. 1991, 1998). Furthermore, immunoelectron microscopy of primate PFC revealed that D1 receptor immunoreactivity is localized in the dendritic spine head and neck, adjacent to an asymmetric synapse from putative excitatory afferents. Remarkably, D1 receptors are frequently found to be present extrasynaptically from nearby dopamine terminals, suggesting their role in volume transmission/ neuromodulation (Smiley and Goldman-Rakic 1993).

On the other hand, D5 receptors seemed to be located predominantly on dendritic shafts (Bergson et al. 1995). Both D1 and D5 receptors have also been shown on the axonal terminals of nondopaminergic neurons that form asymmetric (D1 and D5) or symmetric (D5) synapses on to dendritic spines (Bergson et al. 1995; Smiley and Goldman-Rakic 1993). Although present technical limitations have prevented a precise demonstration of the distribution of D1 to D5 receptors along the dendrites in single pyramidal PFC neurons, the available ultrastructural data suggest that dopamine may act: (1) postsynaptically to modulate excitatory (glutamate-mediated) inputs and dendritic excitability; and (2) presynaptically to modulate the axonal terminals of nondopaminergic afferents that synapse onto dendritic spines.

In human PFC, although the densities of D1 and D4 receptor mRNAs are low, they are predominantly enriched in deep layers and are present in significantly greater amounts than D2, D3, and D5 receptor mRNAs (Matsumoto et al. 1996; Meador-Woodruff et al. 1989, 1996). Receptor ligand binding studies in human brain tissues showed that the density of D1 binding sites is an order of magnitude greater than D2 binding sites in frontal cortex (De Keyser et al. 1988; Camps et al. 1989; Cortés et al. 1989). D1 receptor density was found to be higher in superficial layer I-II than in deep layers V-VI (Cortés et al. 1989). As in the rodent, there is a mismatch of dopamine receptor subtype mRNAs and their corresponding binding sites in human PFC. Nevertheless, the significantly greater number of D1 receptors in human, primate, and rat PFC further suggests that D1 receptors may play a central role in modulating signal processing across mammalian species. 
The distinct laminar patterns of dopamine innervation in PFC may be of functional significance. Each cortical lamina receives functionally segregated inputs originating from different cortical and limbic regions (van Eden et al. 1992; Condé et al. 1995; see Table 1 for a summary for rat PFC). For a deep layer V-VI PFC neuron with a long apical dendrite extending through several cortical layers and potentially receiving inputs from diverse sources, it is likely that dopamine differentially modulates these afferents. Mesocortical dopamine modulation of different inputs to the different dendritic compartment along the different layers may profoundly change the ultimate functional output of that neuron. In principle, this functional modulation is likely to be applicable to both primate and rodent PFC (with some expected species-specific variations). The neuronal model of dopamine modulation of PFC neurons developed below is based primarily on anatomic and electrophysiologic results regarding rodent mesocortical dopaminergic function.

\section{PFC Output Neurons to the Dopamine Terminal Field in the NAc and to the Dopamine Perikaya in the VTA}

Among many subcortical sites that PFC output neurons project to, layer V7-VI pyramidal neurons in primate and rodent PFC have been shown anatomically to project to both NAc and VTA (Phillipson 1979; Sesack et al. 1989; Sesack and Pickel 1992; Berendse et al. 1992a, 1992b; Gorelova and Yang 1997a; Yang et al. 1997b). When recorded in freely behaving primates or rats, these deep layer V-VI neurons showed significant enhancement of firing during a typical "delayedresponse" task, during which specific information must be "held" briefly to guide subsequent responses (Suzuki and Azuma 1977; Sakai and Hamada 1981; Batuev et al. 1990; Funahashi et al. 1989; Funahashi and Kubota 1994; Fuster 1995). This sustained active neuronal activity has been suggested as a cellular correlate of shortterm working memory. The enhanced neural activity occurs during the period when the animal (including humans) must hold items of information, to manipulate and to associate them with other incoming information. Thus, this PFC neuronal process may provide the animal with "the ability to form internal representations of (the) external world for planning, organizing, and guiding of forthcoming response sequences based on ideas and thoughts instead of immediate external stimulations" (Goldman-Rakic 1996).

A sustained enhancement of delayed period firing and successful performance of these tasks are highly dependent on, not only an intact functional mesocortical dopaminergic input (Brozowski et al. 1979; Simon et

Table 1. Summary of Known Afferents from Diverse Brain Regions that Terminate in Different Layers of Rat PFC

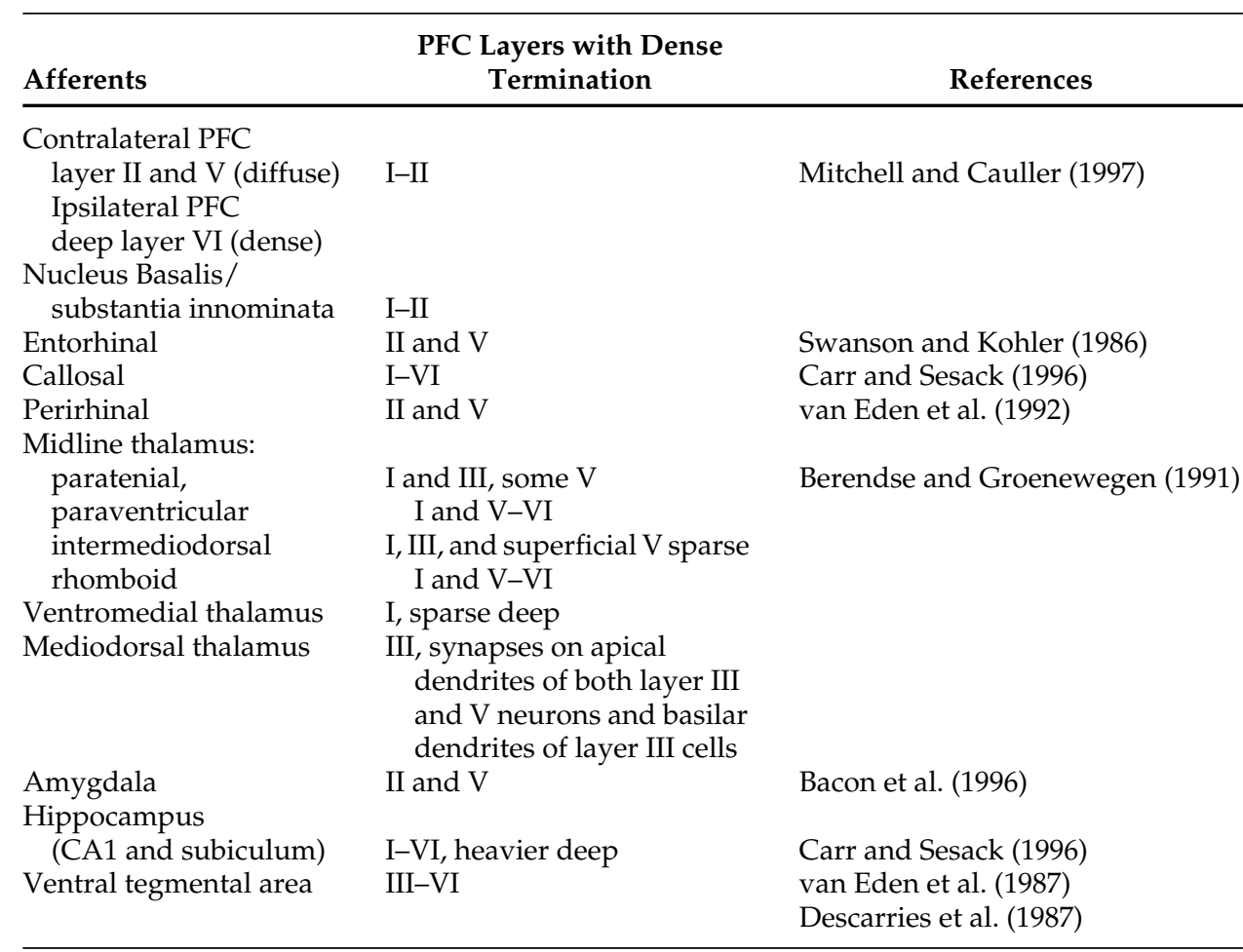


al. 1980; Sawaguchi 1987; Sawaguchi et al. 1990a, 1990b; Sawaguchi and Goldman-Rakic 1994; Seamans et al. 1998), but an "optimal" level of dopamine must also be available (Williams and Goldman-Rakic 1995; Murphy et al. 1996; Watanabe et al. 1997; Zahrt et al. 1997; Seamans et al. 1998). A disruption of neural processes in the PFC has been attributed to many forms of psychopathology underlying schizophrenia (Goldman-Rakic 1991, 1994; Gold et al. 1992; Goldberg and Gold 1995). Clearly, the level of PFC dopamine is critical for modulating normal cognitive/behavioral processes. Deviation from the critical levels can severely disrupt cognitive processes and result in such mental disorders as schizophrenia. At present, how such levels of dopamine interact with PFC neural circuits is not known.

\section{Electrophysiological Actions of Dopamine on PFC Neurons}

The cellular bases of dopamine's actions in the neocortex are enigmatic. In vivo extracellular single-unit recording studies have shown that iontophoretically applied dopamine either increases or decreases spontaneous neuronal firing in the neocortex (Bunney and Aghajanian 1976; Reader et al. 1979; Bradshaw et al. 1985; Sesack and Bunney 1989; Bassant et al. 1990; Yang and Mogenson 1990). Spontaneous activity of rat PFC neurons in deep layer V-VI, where the densest mesocortical dopamine projection innervates were shown to be more sensitive to exogenous dopamine than neurons in the superficial layers I-III (Bunney and Aghajanian 1976). A significant portion of the spontaneous activity being suppressed either by local iontophoretic application of dopamine within the PFC, or by low-frequency $(1 \mathrm{~Hz})$ VTA stimulation, is likely to involve a dopamine activation of GABAergic neurons intrinsic to the PFC (Pirot et al. 1992). (These findings are reviewed in later sections in greater detail).

The modulatory interactions of dopamine with other transmitters has also been the subject of intense investigation. Dopamine applied iontophoretically or released by VTA stimulation, suppressed spontaneous, as well as presumed glutamate-mediated (Pirot et al. 1994) mediodorsal thalamic-evoked firing in the rat PFC in vivo (Bunney and Aghajanian 1976; Ferron et al. 1984; Godbout et al. 1991; Pirot et al. 1994, 1996; Sesack and Bunney 1989; Yang and Mogenson 1990). In contrast, PFC neuronal firing induced by iontophoretic application of acetylcholine or NMDA is enhanced by very low doses of iontophoretically applied dopamine (Cépeda et al. 1992a; Yang and Mogenson 1990). As detailed below, the mechanisms of direct action of dopamine on PFC neurons are rather complex, and thus, it is inappropriate to conclude that dopamine is an inhibitory transmitter based strictly on extracellular findings that simply showed a suppression of spontaneous or synaptically evoked firing (Ferron et al. 1984; Sesack and Bunney 1989; Godbout et al. 1991; Pirot et al. 1992, 1994; Yang and Mogenson 1990).

\section{Ionic Bases of Direct Dopamine Actions on Pyramidal Neurons in the PFC}

Early in vivo intracellular recordings have revealed a very complex picture of dopamine actions in rat frontal cortical neurons. In etherized, artificially ventilated rats, iontophoretic application of dopamine has been shown to induce membrane depolarization of PFC neurons and concomitant suppression of all ongoing spontaneous firing in vivo. These effects were accompanied by little or no change in input resistance (Bernardi et al. 1982). In the same preparation, iontophoretic application of dopamine has been shown to raise the firing threshold induced by iontophoretically applied glutamate. Although these initial intracellular studies have provided useful information regarding the actions of dopamine on PFC neurons in vivo, they could not provide hints to the ionic mechanisms underlying the actions of dopamine.

The recent characterization of dopamine actions on pyramidal layer V-VI PFC neurons (some were retrogradely labeled to be NAc-projecting neurons) has enabled a more detailed understanding of the actions of dopamine in the PFC in vitro (Yang and Seamans 1996). A brief period (30-90 s) of bath application of dopamine or the D1/5 agonists (SKF38393 or SKF81297) to rat PFC slices has been shown to induce highly variable small changes in membrane potential and input resistance in the layer V-VI PFC neurons. In another PFC slice study, 1 to 5 minutes of application of dopamine in the presence of ascorbic acid (as antioxidant), induced a dosedependent small membrane depolarization (0.5 to 5 $\mathrm{mV}$ ) that cannot be blocked by D1, D2, D4, alpha- , and beta-adrenergic antagonists (Shi et al. 1997). Therefore, dopamine does not exert a consistent action on inactive PFC neurons, which displayed little or no spontaneous activity in vitro (because of the removal of their excitatory afferents from the brain slice preparation procedures).

If these PFC neurons were depolarized by intracellular injection of depolarizing current pulses (which mimicked a selective postsynaptic depolarization) or long depolarizing current ramps, a brief period of bath applications (30-90 s) of dopamine D1/5 agonists lowered the firing threshold of the first spike and reduced the first spike latency evoked by the depolarizing pulses (Penit-Soria et al. 1987; Yang and Seamans 1996; Shi et al. 1997; Gorelova and Yang, submitted) (Figure 2). These responses were similar, whether the recordings were made at room (whole cell patch-clamp recordings at $23^{\circ} \mathrm{C}$ ) or at a more phyisological temperature (intra- 
cellular recordings at $34^{\circ} \mathrm{C}$ ). The short duration application time 30-90 s) implemented in these studies served to minimize rapid D1 receptor desensitization (Jarvie et al. 1993; Ng et al. 1994, 1995; Dumartin et al. 1998).

More recently, other intracellular and patch-clamp studies also detected an early transient suppression of input resistance that results in a late onset of first spike latency (responses start at $\sim 2$ min after a 5-min long dopamine or D2/3/4 agonist application with the re- sponses lasting for $\sim 5 \mathrm{~min}$ ) (Geijo-Barrientos and Pastore 1995; Gulledge and Jaffe 1998). Responses from some of the same cells also show a delayed increase in neuronal excitability, as shown by a rebound earlier onset of first spike latency evoked by the same depolarizing pulse in PFC pyramidal neurons (Gulledge and Jaffe 1998). Thus, for a given depolarizing input, postsynaptic D1/5 and D2/3/4 dopamine receptor stimulation may induce time-dependent changes in ionic con-
CONTROL

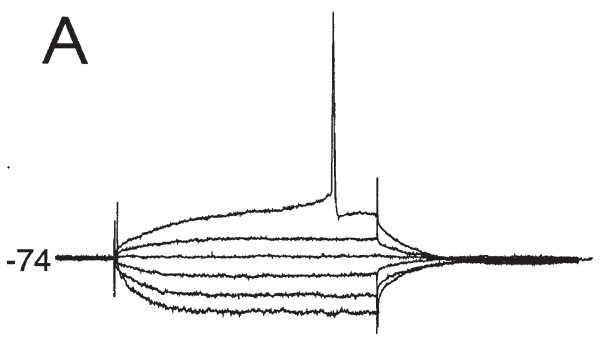

B

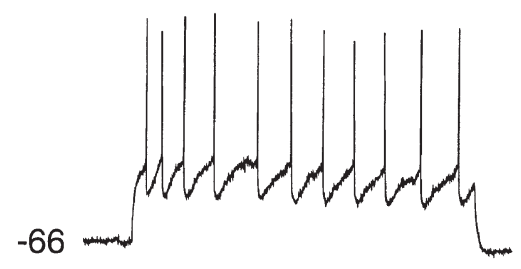

CONTROL

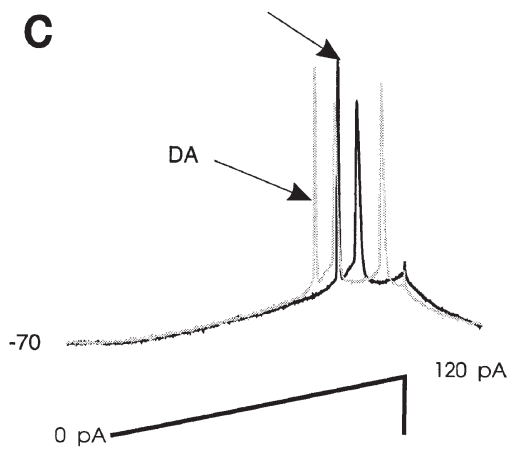

$10 \mu \mathrm{M}$ SKF 81297

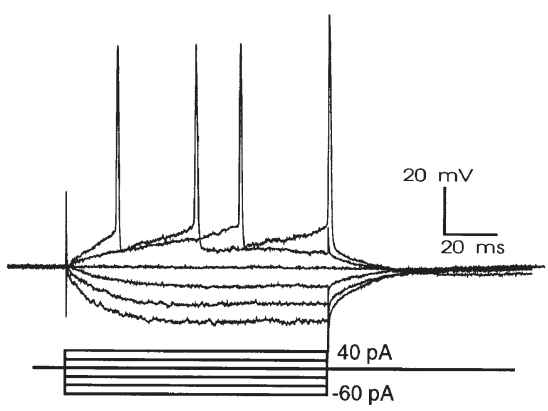

$20 \mu \mathrm{M}$ SKF38393
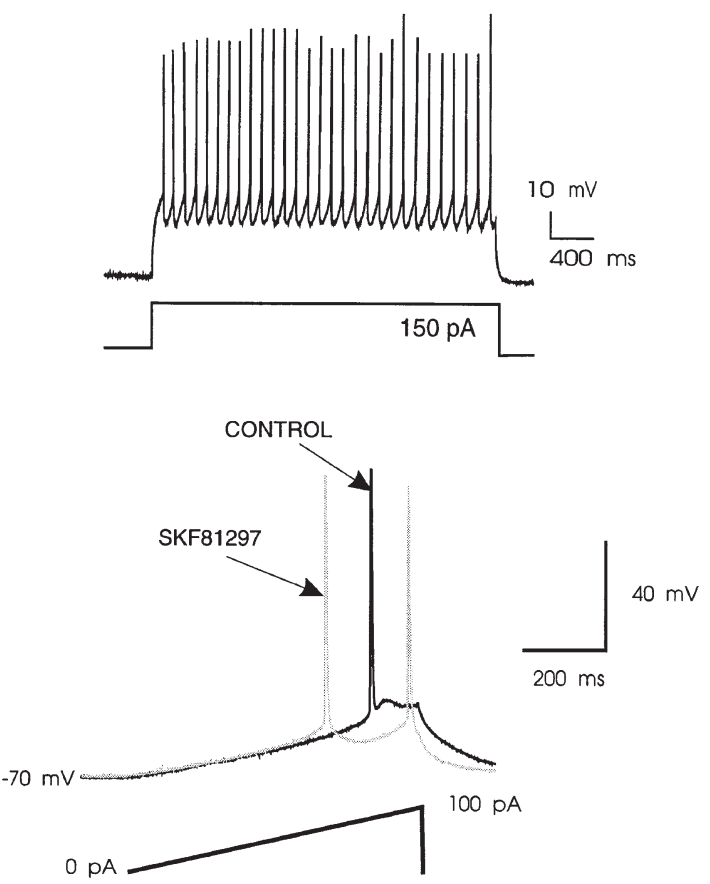

Figure 2. Postsynaptic D1 receptor stimulation by the D1 agonists SKF81297 or SKF38393 evokes repetitive firing in PFC pyramidal neurons in response to a given depolarizing current pulse. (A)(left) intracellular injection of a short (70 ms) depolarizing current pulse evoked one spike. (right) bath-application of $10 \mu \mathrm{m}$ SKF81297 resulted in lowering of spike threshold and repetitive firing in response to the same depolarizing current pulse; (B) If a longer (1 s) depolarizing pulse was injected intracellularly to induce repetitive firing, the presence of another D1 agonist SKF38393 transformed the isolated firing pattern to vigorous spike trains for the same given depolarizing pulse; (C) Reduction of first spike latency by dopamine $(4 \mu \mathrm{m}$, left) and SKF81927 (4 $\mathrm{mm}$, right) in response to slow depolarizing ramps in PFC pyramidal neurons. The current-clamp records are from whole-cell patch clamp recordings at $25^{\circ} \mathrm{C}$ and taken at $\sim 9 \mathrm{~min}$ after a brief application of dopamine and its D1/5 agonist. Note that there is no change in the slope of the response, suggesting that the response is not accompanied by changes in input resistance at this time point. 
ductances that alter the threshold for firing in PFC neurons. The D2/3/4 receptor may induce an early transient suppression of neuronal excitability; whereas, D1/5 receptor activation may induce a late, prolonged enhancement of neuronal excitability in response to depolarizing inputs. These findings also indicate that until there is a change in the firing activity or voltage-dependent, active membrane properties of the PFC neuron, it would be difficult to detect the modulatory actions of dopamine clearly. Thus, for a better understanding of dopaminergic modulation, the basic properties of these voltage-dependent active membrane currents that specifically regulate the firing threshold of pyramidal PFC neurons are reviewed below.

\section{Possible Soma-Dendritic Compartmentalized Actions of Dopamine in Pyramidal PFC Neurons}

Control of Firing Threshold in PFC Pyramidal Cells. In cortical and hippocampal pyramidal neurons, the spike firing threshold is determined by the interaction of $\mathrm{Na}^{+}$current, high- and low-voltage-activated $\mathrm{Ca}^{2+}$ currents and outwardly rectifying $\mathrm{K}^{+}$currents (Connors et al. 1982; Sutor and Zieglgansberger 1987; Schwindt 1992; Magee et al. 1996). In the PFC pyramidal neurons, at least two major cationic conductances control firing threshold. Up to $30 \mathrm{mV}$ positive from resting membrane potential and before initiation of an action potential, a TTX or QX-314-sensitive, slowly inactivating persistent $\mathrm{Na}^{+}$current $\left(\mathrm{I}_{\mathrm{NaP}}\right)$ is readily activated in pyramidal PFC neurons (Geijo-Barrientos and Pastore 1995; Yang et al. 1996a; Gorelova and Yang 1997b). Within this narrow voltage range subthreshold to firing, this $\mathrm{I}_{\mathrm{NaP}}$ is also responsible for mediating the subthreshold membrane oscillations in diverse types of neocortical neurons, including some types of PFC pyramidal neurons (Connors et al. 1982; Stafstrom et al. 1985; Alonso and Klink 1993; Klink and Alonso 1993; Llinas et al. 1991; Geijo-Barrientos and Pastore 1995; Yang et al. 1996a; Gorelova and Yang 1997b).

Recent electrophysiological results, including those obtained from single $\mathrm{Na}^{+}$channel recordings in acutely isolated cortical pyramidal cells, favor the idea that a single class of $\mathrm{Na}^{+}$channels can switch periodically to a sustained opening mode interspersed with short duration transient openings. When in the sustained opening mode, inactivation of the $\mathrm{Na}^{+}$channel is temporarily lost (Alzheimer et al. 1993; Moorman et al. 1990; Brown et al. 1994). Thus, subthreshold $\mathrm{I}_{\mathrm{NaP}}$ and the transient $\mathrm{Na}^{+}$current responsible for spike firing are conducted via the same population of $\mathrm{Na}^{+}$channels, which are undergoing two kinetically different gating modes. The factors or mechanisms that govern the switching of $\mathrm{Na}^{+}$ channels between the slow inactivating persistent mode and the transient mode in the PFC pyramidal neurons are not known.
Tetrodotoxin-sensitive $\mathrm{Na}^{+}$channels are present in both the dendrites and the soma of pyramidal cells, as suggested by electrophysiological and $\mathrm{Na}^{+}$-imaging studies (Huguenard et al. 1989; French et al. 1990; Jaffe et al. 1992; Kim and Connors 1993; Regehr et al. 1993; Stuart and Sakmann 1994; Schwindt and Crill 1995; Crill 1996). However, the soma and the axon hillock have the densest distribution of immunohistochemically identified $\mathrm{Na}^{+}$channels subunits (Westenbroek et al. 1989). Functionally, activation of the $\mathrm{Na}^{+}$current generated near the axosomatic region of cortical pyramidal neurons by synaptic inputs (e.g., following stimulation of superficial layers I-II) can serve to "amplify" the subthreshold distal synaptic signals en route to the soma of the deep layer V-VI cortical pyramidal neuron (Schwindt and Crill 1995; Stuart and Sakmann 1995).

The depolarizing action of this $\mathrm{I}_{\mathrm{NaP}}$ is strongly counteracted by a 4-aminopyridine- and dendrotoxin-sensitive, slowly inactivating $\mathrm{K}^{+}$conductance (Yang et al. 1996a). The $\mathrm{K}^{+}$current responsible for this conductance is inactive at rest and requires prior hyperpolarization to remove the inactivation fully. Hence, although this current is activated within 100 to $200 \mathrm{~ms}$, it often takes many seconds to inactivate (Hammond and Crépel 1992). This voltage-dependent $\mathrm{K}^{+}$current resembles the slowly inactivating outward $\mathrm{K}^{+}$current, $\mathrm{I}_{\mathrm{D}}$ or $\mathrm{I}_{\mathrm{K} s}$, which has also been characterized in hippocampal, striatal, and somatosensory cortical neurons (Schwindt et al. 1988; Storm 1988; Foehring and Surmeier 1993; Nisenbaum et al. 1996). As $I_{K S}$ functionally counteracts excessive and sustained membrane depolarization, it could effectively raise the spike threshold and suppress repetitive spike firing.

Presently, there has been no evidence for the precise locations of this $\mathrm{K}^{+}$channel along the soma-dendritic compartment of a typical pyramdal neuron in the PFC. The fact that this $\mathrm{K}^{+}$current can be recorded in acutely dissociated neurons where most of the apical and basal dendrites are lost suggested a somatic or near-somatic origin of this current. The "see-saw" opposing interplay of the slowly inactivating $\mathrm{Na}^{+}$and $\mathrm{K}^{+}$currents in the narrow membrane voltage range between -70 to -55 $\mathrm{mV}$ controls the threshold voltages for spike firing in PFC neurons. Transmitter modulation of either or both of these currents can profoundly alter firing threshold and can result in the subsequent initiation or suppression of regenerative spike train outputs.

\section{Ionic Mechanisms That Regulate Spike Firing Threshold in PFC Neurons and Their Modulation by Dopamine}

PERSISTENT $\mathrm{Na}^{+}$CURRENT $\left(\mathrm{I}_{\mathrm{NAP}}\right)$. Following the blockade of $\mathrm{Ca}^{2+}$ and $\mathrm{K}^{+}$currents (using $\mathrm{Co}^{2+}$, TEA, and/or 4 -aminopyridine in the perfusate, and using $\mathrm{Cs}^{+}$-con- 
taning recording electrode), current-clamp intracellular or whole-cell patch-clamp recordings in deep layer V-VI neurons of the PFC or somatosensory cortical neurons have revealed that a brief intracellular depolarizing pulse activates a sustained $\mathrm{Na}^{+}$plateau potential that is accompanied by superimposed membrane oscillations. The plateau potential is mediated by a $\mathrm{Na}^{+}$current, because reducing $\mathrm{Na}^{+}$content of the perfusate markedly reduces this potential, and TTX or internal QX-314 abolishes it (Stafstrom et al. 1985; Fleidervish and Gutnick 1996; Yang et al. 1996a; Yang and Seamans 1996). D1/5 receptor stimulation (by SKF38393) augments the duration of this $\mathrm{Na}^{+}$plateau potential and shifts the activation threshold to a more negative voltage. This finding suggests that D1/5 receptor stimulation lowers the activation threshold and delays the inactivation of the slowly inactivating $\mathrm{Na}^{+}$conductance (Yang and Seamans 1996).

The effects of dopamine on a putative $\mathrm{I}_{\mathrm{NaP}}$ (in the absence of any blockers for $\mathrm{Na}^{+}$or $\mathrm{K}^{+}$currents) were reported recently in striatal and PFC pyramidal neurons. In rat striatal slices using whole-cell patch-clamp recordings, dopamine reduces the peak amplitude of a putative slowly inactivating $\mathrm{Na}^{+}$current evoked by a slow depolarizing volatge ramp (Cépeda et al. 1995). In PFC pyramidal neurons recorded in rat brain slices using sharp electrode under single electrode voltage clamp mode, bath application of dopamine $(10 \mu \mathrm{m})$ briefly suppresses an inward current recorded during depolarizing steps in voltage range from $-50 \mathrm{mV}$ to $\sim-45 \mathrm{mV}$ (fast $\mathrm{Na}^{+}$spike threshold in their experiments)(Geijo-Barrientos and Pastore 1995). It should be noted that several ionic conductances, in addition to the slow $\mathrm{I}_{\mathrm{NaP}}$, contribute to the generation of the inward current in this subthreshold voltage range. Inward currents include low-threshold $\mathrm{Ca}^{2+}$ conductance (T-current), and mixed $\mathrm{K}^{+}$and $\mathrm{Na}^{+}$conductance (so-called $\mathrm{I}_{\mathrm{h}}$, which was shown to be active at resting membrane potentials in cortical neurons). Outward currents include a leak, and an outwardly rectifying $\mathrm{K}^{+}$current can also shape the sum current during the depolarizing voltage step or ramp. Co-activation of this mixture of currents in the absence of their blockade makes it uncertain which current was suppressed or enhanced by dopamine in PFC neurons.

We recently attempted to use whole-cell patchclamp recordings in layer V-VI PFC pyramidal neurons under voltage-clamp mode in rat PFC slices to examine the effects of dopamine on pharmacologically isolated slow inactivating $\mathrm{Na}^{+}$current (Gorelova and Yang 1997b). When $\mathrm{Ca}^{2+}$ and $\mathrm{K}^{+}$channels are blocked by extracellular $\mathrm{Cd}^{2+}, \mathrm{TEA}$ and internal $\mathrm{Cs}^{+}, \mathrm{D} 1 / 5$ agonists (SKF38393, SKF81297, bath-applied for 60-90 s) resulted in a leftward shift of the activation of this $\mathrm{I}_{\mathrm{NaP}}$ current so that the current could be activated at a more hyperpolarized potential. This effect is most prominent
10 min after the application of dopamine or the D1/5 agonists. This leads to an apparent increase of peak inward $\mathrm{Na}^{+}$current in voltage range from $-60 \mathrm{mV}$ to $-45 \mathrm{mV}$, but a decrease of this current at potentials more positive than from -40 to $-35 \mathrm{mV}$. In addition, there is an increase in the time-constant of inactivation of this current, suggesting that this current takes even longer to inactivate completely following D1/5 receptor stimulation (Gorelova and Yang 1997b, 1998). Thus, following D1/5 receptor stimulation, the combined effect of an earlier onset of activation of the persistent $\mathrm{Na}^{+}$current at a more hyperpolarized potential, and the delayed inactivation of this current may ensure that the depolarizing effects of the $\mathrm{Na}^{+}$current persist. Because of the extensive dendritic arbor of the PFC pyramidal neurons and the inherent space-clamp problem, it is difficult to determine whether there was an adequate voltage-clamp control of the responses of the $\mathrm{I}_{\mathrm{NaP}}$ in this study. However, if the $\mathrm{I}_{\mathrm{NaP}}$ responses are recorded within close vicinity of the recording pipette in the soma-basal dendritic compartment (as suggested from immunohistochemical findings of the distribution of subunits of $\mathrm{Na}^{+}$channels in pyramidal neurons, Westenbroek et al. 1989), adequate voltage-clamp of the $\mathrm{I}_{\mathrm{NaP}}$ are likely to have occurred, then these results may provide the ionic bases via which $\mathrm{D} 1 / 5$ receptor activation lower the threshold of first spike initiation to generate the subsequent repetitive firing in response to a subthreshold depolarizing pulse (Yang and Seamans 1996).

Transient Fast $\mathrm{Na}^{+}$Current. The effects of dopamine on the fast $\mathrm{Na}^{+}$current was most well studied in striatal neurons. Because the fast $\mathrm{Na}^{+}$currents are conducted via the same $\mathrm{Na}^{+}$channels that conduct the slow peresistent $\mathrm{Na}^{+}$currents $\mathrm{I}_{\mathrm{NaP}}$, but only in different gating modes (Alzheimer et al. 1993; Moorman et al. 1990; Brown et al. 1994), we hope by reviewing some of the striatal findings, we may be able to gain some insights into the nature of dopamine modulation of $\mathrm{Na}^{+}$ current in PFC neurons. Adequate voltage control can be obtained from voltage-clamp studies in acutely dissociated, retrogradely prelabeled striatonigral neurons, hippocampal, nucleus accumbens, and cultured striatal neurons. D1/5 receptor agonists reduce the peak amplitude of the fast $\mathrm{Na}^{+}$current in all these cell types (Surmeier et al. 1992; Schiffmann et al. 1995; Cantrell et al. 1997; Zhang et al. 1998). In striatonigral neurons, a kinetic shift of its voltage-dependence of the steady-state inactivation of the $\mathrm{Na}^{+}$current to a more negative potential is also observed (Surmeier et al. 1992). This result suggests that D1/5 receptor stimulation reduces the number of $\mathrm{Na}^{+}$channels available for activation. This action of dopamine, via its D1/5 receptor, may partly account for the typical dopamine suppression of intracellular depolarizing pulse-evoked spike firing at resting potential in rodent or human striatal neurons 
(Calabresi et al. 1987; Cépeda et al. 1992b; HernándezLópez et al. 1997).

Brain $\mathrm{Na}^{+}$channels are modulated via either phosphorylation by protein kinase $\mathrm{C}$ (PKC) and protein kinase A (PKA)(Numan et al. 1991; Smith and Goldin 1997). Activation of PKA reduced fast $\mathrm{Na}^{+}$current, but did not change its activation or inactivation (Schiffmann et al. 1995; Smith and Goldin 1997; Zhang et al. 1998). In PFC neurons, voltage-clamp studies of the effects of dopamine on the transient fast $\mathrm{Na}^{+}$current have not been reported. Nevertheless, a recent study in mouse cortical neurons shows that activation of PKC by intracellular phorbal ester results in a reduction of the $\mathrm{I}_{\mathrm{NaP}}$ only at depolarized potential more positive than $-40 \mathrm{mV}$ (Astman et al. 1998). However, this is accompanied by a delayed (peak at $4 \mathrm{~min}$ ) shift in the activation of this current to hyperpolarized potentials more negative than $-40 \mathrm{mV}$; hence, resulting in a significant increase in the $\mathrm{I}_{\mathrm{NaP}}$ in this membrane voltage range (Astman et al. 1998). These changes in $\mathrm{I}_{\mathrm{NaP}}$ kinetics by PKC activation are remarkably similar to that following dopamine or D1/5 agonist application in PFC neurons as mentioned above (Gorelova and Yang, submitted; Gorelova and Yang 1997b). There is some evidence for activation of PKC by dopamine and D1 agonists (McMillian et al. 1992; Kansra et al. 1995). This finding raises the question of whether dopamine may modulate $\mathrm{I}_{\mathrm{NaP}}$ in PFC neurons via activation of PKC; whereas, dopamine induces changes in fast $\mathrm{Na}^{+}$current in striatal neurons via activation of PKA.

SLOWLY INACTIVATING $\mathrm{K}^{+}$CURRENT. As mentioned above, another major current that operates in the membrane voltage range just subthreshold to spike firing is a 4-aminopyridine- and dendrotoxin-sensitive slowly inactivating $\mathrm{K}^{+}$conductance (Storm 1988; Hammond and Crépel 1992; Nisenbaum et al. 1994, 1996). This slow outward $\mathrm{K}^{+}$current is responsible for membrane outward rectification in the depolarized voltage range and functionally opposes the sustained membrane depolarization mediated by the $\mathrm{I}_{\mathrm{NaP}}$ current to prevent PFC neurons from reaching firing threshold (Yang et al. 1996a).

When both $\mathrm{Na}^{+}$and $\mathrm{Ca}^{2+}$ channels are blocked, D1/5 agonists remove a membrane outward rectification caused by this slowly inactivated $\mathrm{K}^{+}$conductance (Yang and Seamans 1996). Recently, Nisenbaum and colleagues (1998) have shown that the full D1/5 agonist SKF82958 blocks a similar slow $\mathrm{K}^{+}$current in striatal neuron. This agonist may exert a novel mechanism of blockade by directly interacting with the $\mathrm{K}^{+}$channel, rather than via activation of the G-protein/adenylate cyclase coupled D1/5 receptor.

Functionally, for a given subthreshold depolaring EPSP that can activate both the $\mathrm{I}_{\mathrm{NaP}}$ and $\mathrm{K}^{+}$currents, $\mathrm{D} 1 / 5$ receptor activation in $\mathrm{PFC}$ neurons effectively removes this slow $\mathrm{K}^{+}$current-mediated hyperpolarizing "brake" on the $\mathrm{I}_{\mathrm{NaP}}$. This reduction of the slow $\mathrm{K}^{+}$conductance by the $\mathrm{D} 1 / 5$ receptor mechanisms can, thus, allow full expression of the depolarizing effects of the $\mathrm{I}_{\mathrm{NaP}}$ (which is simultaneously modulated by dopamine). As a result of all these events, once spike threshold is attained, the ensuing repetitive firing is temporarily sustained (Kitai and Surmeier 1993; Yang and Seamans 1996).

Possible Dopamine Modulation of Synaptic InTEgration Near the Pyramidal Soma/Basal Dendritic COMPARTMENT. The opposing action of the D1 receptor on the slowly inactivating $\mathrm{K}^{+}$and $\mathrm{Na}^{+}$currents can have important functional implications for how PFC neurons process incoming signals. Direct somatic and dendritic recordings during imaging of $\mathrm{Na}^{+}$signals have shown that both $\mathrm{Na}^{+}$spikes and $\mathrm{Na}^{+}$signals exist in the soma and the dendrites of pyramidal neurons (Huguenard et al. 1989; Jaffe et al. 1992; Kim and Connors 1993; Regehr et al. 1993; Stuart and Sakmann 1995). It is not known under what physiological conditions in vivo that the $\mathrm{Na}^{+}$channels in the dendrites or in the soma are preferentially in the "persistent" gating mode. Because subunits of the cloned $\mathrm{Na}^{+}$channel have been shown immunohistochemically to be distributed in close proximity to the soma of a pyramidal neuron (Westenbroek et al. 1989), it is likely that the $\mathrm{I}_{\mathrm{NaP}}$ that is sensitive to dopamine modulation is generated near the proximal apical dendrites and soma/basal dendrites of pyramidal neurons.

The specific location of the slowly inactivating $\mathrm{K}^{+}$ current in pyramidal PFC neurons remains unknown. In a voltage-clamp study of PFC pyramidal neuron in brain slices (Hammond and Crépel 1992), this slow $\mathrm{K}^{+}$ current can be effectively clamped intrasomatically. Furthermore, in acutely dissociated young adult sensorimotor cortical pyramidal neurons, where most of their dendritic arbors are severely truncated, several subtypes of slowly inactivating $\mathrm{K}^{+}$currents were isolated (Foehring and Surmeier 1993). More recently, direct dendritic patch-clamp recordings also show the presence of a high density of the transient A-type fast $\mathrm{K}^{+}$current $\left(\mathrm{I}_{\mathrm{A}}\right)$, but not the slowly inactivating $\mathrm{K}^{+}$current, in the apical dendrites of hippocampal CA1 pyramidal neurons (Hoffman et al. 1997). This evidence suggests that functional $\mathrm{K}^{+}$channels that conduct the slowly inactivating $\mathrm{K}^{+}$current are likely to be present close to the soma.

Via the actions on the slowly inactivated $\mathrm{Na}^{+}$and $\mathrm{K}^{+}$currents, postsynaptic D1/5 receptor stimulation should augment the postsynaptic effects of depolarizing inputs to the soma or proximal/basal dendrites of layer V-VI PFC neurons (Yang et al. 1996b). This action will result in an increase probability of the cell in reaching firing threshold. Anatomically, inputs to the soma or proximal/basal dendrites of deep layers V-VI cortical neurons are known to arise from neighboring recip- 
rocally connected cells within the same cortical region, at least in primate PFC (Levitt et al. 1993; Lewis and Anderson 1995; Kritzer and Goldman-Rakic et al. 1995; Pucak et al. 1996), and in rat somatosensory cortex (Thompson and Deuchars 1997; Markram 1997; Markram et al. 1997b). If such an organization also exists within the prelimbic rat PFC, postsynaptic D1/5 receptor activation may bias layer V-VI neurons to respond preferentially to inputs from these cells within local reciprocally connected neighboring cortical neurons; for example, similar to those present in the PFC "stripes" of primates (Lewis and Anderson 1995; Pucak et al. 1996). This reciprocal interaction may give rise to a reverberative ensemble of local neurons. Such local activity, confined within the PFC, may be operational during working memory processing, because the PFC must rely on sustained firing to "hold" information in the absence of continuous presence of previously presented sensory cues (Amit 1995; Goldman-Rakic 1995; Lewis and Anderson 1995; Yang and Seamans 1996 Durstewitz et al (1999). Paired-cell recordings (Thompson and Deuchars 1997; Markram 1997; Markram et al. 1997b) from interacting pyramidal PFC neurons, and a study of the effects induced by dopamine are critically needed to test this hypothesis.

It should be noted that, in addition to the postsynaptic D1/ 5 receptor effects, recent in vitro electrophysiolocial studies have shown that dopamine, or a D1/5 agonist (SKF81297), can also exert presynaptic inhibitions of glutamatergic layer V-VI afferents in some layer V-VI rat PFC pyramidal neurons (Law-Tho et al. 1994; Yang et al. 1996b; Gulledge and Jaffe 1996). It is not yet known under what in vivo conditions dopamine would activate presynaptic $\mathrm{D} 1 / 5$ receptors preferentially to supress excitatory layer V-VI afferent transmission, or under what other conditions dopamine would activate postsynaptic D1/5 receptors to augment depolarizing inputs. It is conceivable that the timing of the dopamine receptor activation on these pre- and postsynaptic sites critically determines the outcome of signal transmission and computation in layer V-VI PFC neurons.

\section{Apical Dendritic Compartment of Deep Layer Pyramidal Cortical Neurons}

The apical dendrites of typical deep layer V-VI pyramidal neurons in the neocortex (including the PFC) extend $400-1,000 \mu \mathrm{m}$ from the soma before bifurcating into finer dendritic tuft branches (Seamans et al. 1997; Yang et al. 1996a). Synaptic inputs from many other association cortical regions converge in layer I-II, where the apical tuft of the layer V-VI pyramidal neurons extends (Peters 1987; van Eden et al. 1992; Condé et al. 1995; Mitchell and Cauller 1997; Table 2). Distal synaptic signals en route to the deep layer soma of these neurons can be greatly attenuated if the dendritic membrane is functionally passive in nature (Rall et al. 1992; Cauller and Connors 1994). Moreover, recent evidence indicates that there are high densities of $\mathrm{K}^{+}$and mixed cationic currents $\left(\mathrm{I}_{\mathrm{H}}\right)$ in the dendrites (Hoffman et al. 1997; Stuart and Spruston 1998), which produce even greater attenuation of synaptic signals than that expected for a passive dendrite.

Biophysical and neuronal computational analyses have predicted that voltage-gated ionic currents present in the apical dendrites are likely to be functionally in-

Table 2. A Summary of the Positron Emission Tomography Studies of the Interrelationships Between Resting Regional Blood Flow Data and Symptom Profiles in Living Schizophrenics (Liddle et al. 1992; Liddle 1996)

\begin{tabular}{|c|c|c|c|}
\hline Symptom Clusters & Prefrontal Cortex & Association Cortex & Subcortical Areas \\
\hline \multicolumn{4}{|l|}{ Psychomotor poverty } \\
\hline$\downarrow$ Initiation of speech & $\downarrow$ Lateral to medial eft PFC & $\downarrow$ Superior parietal & $\uparrow$ Head of caudate $\mathrm{N}$ \\
\hline$\downarrow$ Expression of affect & $\downarrow$ Anterior anterior cingulate & association cortex & \\
\hline$\downarrow$ Internal generation of actions & & & \\
\hline \multicolumn{4}{|l|}{ Thought disorganization } \\
\hline \multirow{2}{*}{$\begin{array}{l}\text { Disturbances of aspects of } \\
\text { speech production }\end{array}$} & $\downarrow$ Right ventral PFC & \multirow{2}{*}{\multicolumn{2}{|c|}{$\begin{array}{l}\downarrow \text { Angular gyrus } \\
\downarrow \text { Parietal association cortex }\end{array}$}} \\
\hline & $\uparrow$ Right medial PFC & & \\
\hline$\downarrow$ Attention & $\uparrow$ Anterior cingulate & & \\
\hline$\downarrow$ Suppression of interference & $\uparrow$ Mediodorsal thalamus & & \\
\hline $\begin{array}{l}\text { from irrelevant or } \\
\text { inappropriate mental activity }\end{array}$ & & & \\
\hline \multicolumn{4}{|l|}{ Reality distortion } \\
\hline \multirow{2}{*}{\multicolumn{2}{|c|}{$\begin{array}{l}\text { Failure of internal monitoring } \\
\text { resulting in delusion and }\end{array}$}} & $\uparrow$ Left parahippocampus & \multirow{3}{*}{$\begin{array}{l}\uparrow \text { Left ventral striatum } \\
\uparrow \text { Globus pallidus }\end{array}$} \\
\hline & & (medial temporal lobe) & \\
\hline & & $\uparrow$ Left PFC (near Broca's) & \\
\hline \multicolumn{2}{|l|}{ Deficit in the functional link } & $\downarrow$ Posterior cingulate cortex & \\
\hline \multicolumn{4}{|l|}{ between medial temporal } \\
\hline lobe and NAc & & & \\
\hline
\end{tabular}

Adopted from Liddle et al. (1992) and Liddle (1996). 
volved in integrating distal synaptic signals en route to the soma and (Miller et al. 1985; Shepherd et al. 1985; Bernander et al. 1994; Cauller and Connors 1994; Mel 1994; de Shutter and Bower 1994; Midgaard 1994). On the bases of the experimental findings that focal application of $\mathrm{Na}^{+}$(TTX), or $\mathrm{Ca}^{2+}$ channel $\left(\mathrm{Cd}^{2+}\right.$ or $\left.\mathrm{Ni}^{2+}\right)$ blockers onto apical dendrites attenuates distally evoked synaptic potentials, inward cationic currents via $\mathrm{Na}^{+}$, as well as low- and high-voltage-activated $\mathrm{Ca}^{2+}$ channels have been implicated in "amplifying" the propagating distal synaptic signals en route to the soma (Markram and Sakmann 1994; Yuste et al. 1994; Magee and Johnston 1995b; Schwindt and Crill 1995; 1997a, 1997b; Stuart and Sakmann 1995; Lipowsky et al. 1996; Seamans et al. 1997) (Figure 3).
Dendritic high-voltage-activated $\mathrm{Ca}^{2+}$ spikes may subserve multiple functional roles in synaptic signal integration processes in vivo. For example, they are observed following presentation of visual stimuli (Hirsch et al. 1995), whisker stimulation (Svoboda et al. 1997), and during spontaneuous occurrence of hippocampal sharp wave (resulting from complex network-initiated spike bursts) in distal dendrites of pyramidal neurons in anesthetized animals in vivo (Komondi et al. 1998). For a more detailed investigation of the electrophysiological characteristics of dendritic $\mathrm{Ca}^{2+}$ potentials in pyramidal neurons, such potentials are often investigated in brain slices, following blockade of the $\mathrm{Na}^{+}$and $\mathrm{K}^{+}$ channels (by external TTX + TEA, or internal QX-314 + $\left.\mathrm{Cs}^{+}\right)($Franz et al. 1986; Sayer et al. 1990, 1993; Reuveni et

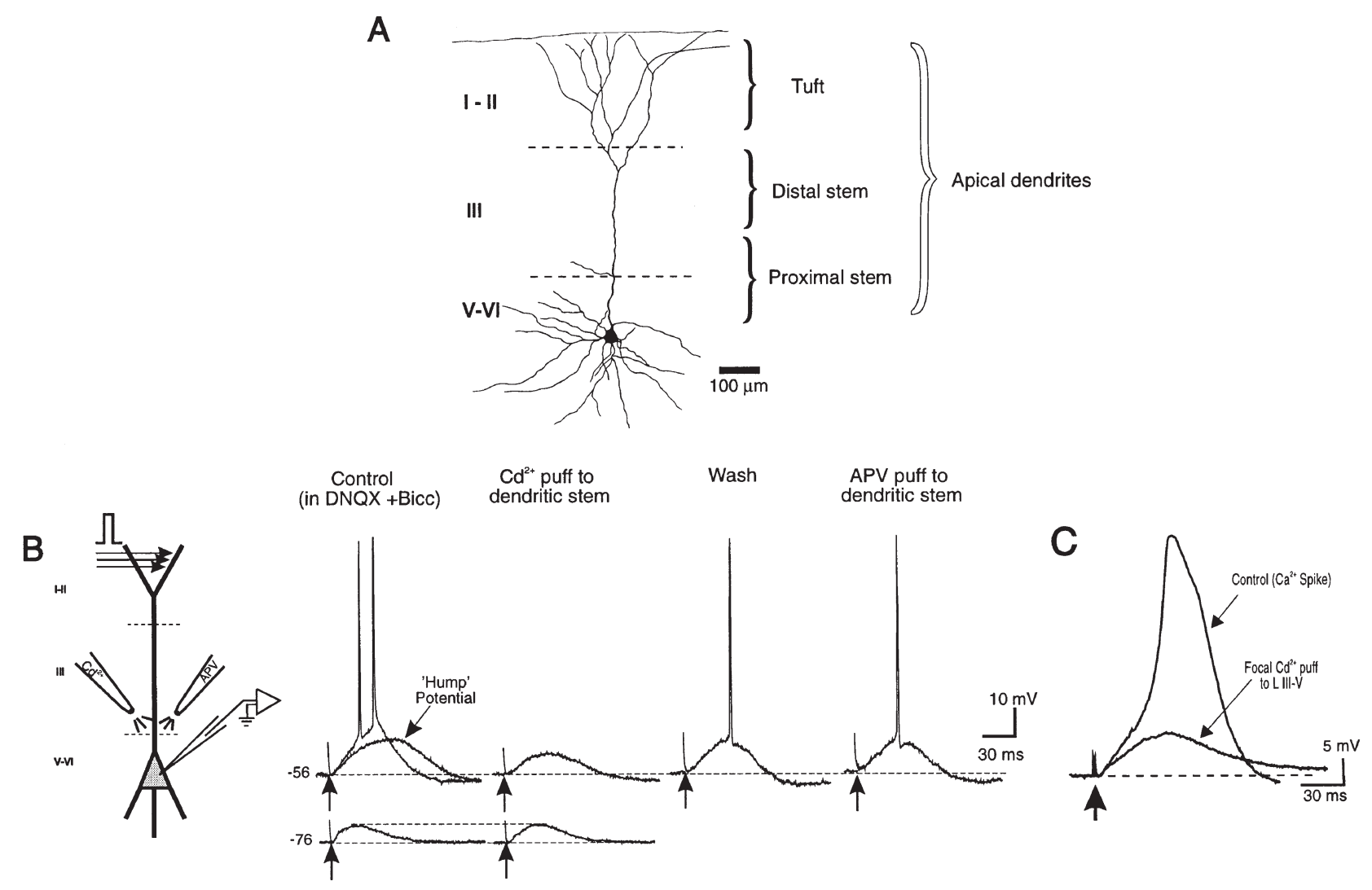

Figure 3. $\mathrm{Cd}^{2+}$-sensitive $\mathrm{Ca}^{2+}$ currents proximal to the soma of layer V PFC neurons enhance responses evoked by stimulation of layers I-II; (A) camera Lucida drawing of a layer V-VI PFC neuron, with the apical dendritic tuft and distal and proximal apical dendritic stem regions demarcated; (B) (left to right) schematic diagram of a layer V-VI PFC neuron and the location of synaptic stimulation as well as the approximate positions of the $\mathrm{Cd}^{2+}$ and the APV-filled pressure ejection pipettes. Synaptic stimulation of layers I-II (in the presence of bath applied DNQX, $10 \mu \mathrm{M}$ and Bicuculline, $4 \mu \mathrm{m}$ ) evoked either a large subthreshold NMDA EPSP or a suprathreshold response at a $\mathrm{V}_{\mathrm{m}}$ of $-56 \mathrm{mV}$. Note the "hump"-like potential during the late portion of the subthreshold EPSP. At a $V_{m}$ of $-76 \mathrm{mV}$, a smaller subthreshold NMDA-EPSP was evoked. $\mathrm{Cd}^{2+}$ application to the proximal apical dendritic stem region (100-200 $\mu \mathrm{m}$ from the soma) reduced the large subthreshold EPSP and abolished synaptically evoked action potentials, while having no effect on the EPSP evoked at $-76 \mathrm{mV}$. This suggests that the dendritic $\mathrm{Ca}^{2+}$ "hump" potential mainly amplifies subthreshold EPSPs. Following partial recovery from the effects of $\mathrm{Cd}^{2+}$ application, focal application of APV to the same site had no effect on the evoked response. In all figures, an arrow denotes the time of synaptic stimulation; $(C) \mathrm{Cd}^{2+}$ application to the proximal dendrites also blocks the high-voltageactivated dendritic $\mathrm{Ca}^{2+}$ spike synaptically evoked by layer I-II stimulations. 
al. 1993; Seamans et al. 1997). Under these conditions, multiphasic soma-dendritic high-voltage-activated $\mathrm{Ca}^{2+}$ potentials, activated from $-50 \mathrm{mV}$, have been recorded from soma and in different regions of the apical dendrites of pyramidal PFC or somatosensory cortical neurons directly (Amitai et al. 1993; Kim and Connors 1993; Seamans et al. 1997; Schiller et al. 1997) (Figure 4).

Combined pharmacological, electrophysiological, and $\mathrm{Ca}^{2+}$ imaging studies have shown that high- and lowvoltage-activated $\mathrm{Ca}^{2+}$ channels distribute widely, but heterogeneously, throughout the soma and the apical dendrites of pyramidal neurons (Brown et al. 1993; Kim and Connors 1993; Mills et al. 1994; Yuste et al. 1994; Markram et al. 1995; Schiller et al. 1995; Miura et al. 1997). These soma-dendritic $\mathrm{Ca}^{2+}$ channels include T-, L-, P/Q, and N-types (Hillman et al. 1991; Ye and Akaike 1993; Markram and Sakmann 1994; Magee and Johnston 1995a, 1995b; Kavalali et al. 1997a). L-type channel immunoreactivity is distributed primarily in the soma/basal dendrite/proximal apical dendrite compartment; whereas, N-type channel immunoreactivity is distributed throughout the apical dendrites of pyramidal neurons (Westenbroek et al. 1990, 1992; Hell et al. 1993). In addition to functional amplification of subthreshold synaptic signals en route to the soma, these dendritic $\mathrm{Ca}^{2+}$ channels provide a support mechanism for local regeneration of dendritic spikes necessary for somatic burst firing, the induction of Hebbian forms of synaptic plasticity (Friedman and Gutnick 1989; Yuste and Tank 1996; Johnston et al. 1996; Magee et al. 1998), and intracellular $\mathrm{Ca}^{2+}$ signaling (Berridge 1998).

Direct dendritic recordings in the distal dendritic tufts, where fine dendritic branches bifurcate from the main apical dendritic stem of deep layer V-VI pyramidal PFC neurons, have shown that evoked dendritic $\mathrm{Ca}^{2+}$ mediated potentials are rare (Seamans et al. 1997). When present in the apical tuft, $\mathrm{Ca}^{2+}$ potentials are initiated at very high threshold. In contrast, dendritic stem regions proximal to the soma, somatic, and dendritic stem recordings have shown that a $\mathrm{Cd}^{2+}$ - or nimodipine(L-type $\mathrm{Ca}^{2+}$ channel antagonist) sensititive "hump" potential can be elicited by local depolarizing pulse injections or stimulations of synaptic inputs to the distal dendritic tuft in layer I-II (Seamans et al. 1997). Because this $\mathrm{Ca}^{2+}$ "hump" potential is activated below $\mathrm{Na}^{+}$ spike threshold, the "hump" potential may functionally boost the amplitude and duration of subthreshold distal EPSPs en route to the soma (Seamans et al. 1997). When stronger orthodromic synaptic inputs or local depolarizing current pulses are delivered, the evoked "hump" potentials in PFC pyramidal neurons trigger large amplitude, multiphasic and/or regenerative highvoltage- activated $\mathrm{Ca}^{2+}$ spikes along the apical stem, soma, or the basal dendrites (Seamans et al. 1997, Figure 4). These spikes may be involved in burst genera- tion or internal $\mathrm{Ca}^{2+}$ signaling mechanisms. They may also help to amplify the propagation of $\mathrm{Na}^{+}$spikes back into the apical dendrites (Durstewitz and Seamans submitted).

Activation of dendritic high-voltage-activated $\mathrm{Ca}^{2+}$ channels is mediated by complex mechanisms (Figure 5). Sodium spike transients are generally required for triggering dendritic $\mathrm{Ca}^{2+}$ channel activation (Chen et al. 1997; Colbert and Johnston 1996; Komondi et al. 1998; Markram et al. 1995; Schiller et al. 1995; Stuart and Sakmann 1994). In most cases, $\mathrm{Na}^{+}$spikes are initiated in the axon and backpropagate into the apical dendrite (Stuart and Sakmann 1994; Stuart et al. 1997; Colbert and Johnston 1996), where they have been shown to activate dendritic high-voltage-activated $\mathrm{Ca}^{2+}$ channels both in vitro and in vivo (Buzsáki and Kandel 1998; Markram et al. 1995; Schiller et al. 1995; Spruston et al. 1995; Stuart and Sakmann 1994; Svoboda et al. 1997). Notably, when the timing of the arrival of the fast retrograde $\mathrm{Na}^{+}$spikes temporally coincides with the afferent synaptic inputs, this $\mathrm{Na}^{+}$spike-induced dendritic $\mathrm{Ca}^{2+}$ influx is supralinear (i.e., greater than the linear sum of the effects of a backpropagated spike plus a synaptic input alone), and enduring changes in synaptic efficacy and strength of the previously weak afferent are induced (Markram et al. 1997a; Magee and Johnston 1997).

Under other conditions, $\mathrm{Na}^{+}$spikes may also be initiated locally in the dendrites to trigger local dendritic $\mathrm{Ca}^{2+}$ potentials. Conditions that induce local dendritic $\mathrm{Na}^{+}$spikes include strong orthodromic depolarizing synaptic inputs, or focal ionotphoresis of glutamate to induce tonic dendritic depolarization (Regehr et al. 1993; Regehr and Tank 1990, 1992; Stuart and Sakmann 1994; Stuart et al. 1997; Schwindt and Crill 1995, 1998). To dissociate the contribution of the soma vs. dendrite $\mathrm{Na}^{+}$spike initiation, some studies have attempted to "inactivate" $\mathrm{Na}^{+}$spike-generating mechanisms near the axosomatic regions by: (1) making a physical cut to separate the soma from the apical dendrite; (2) applying focal TTX application in the soma region; or (3) voltage clamping the soma to a very hyperpolarized potential (Regehr et al. 1993; Masukawa and Prince 1984; Schwindt and Crill 1997a). Although there are inherent problems with each approach, it nevertheless seems that $\mathrm{Na}^{+}$spikes can be initiated locally in the dendrites and that the large voltage changes produced by such spikes likely provide an effective means of activation for dendritic $\mathrm{Ca}^{2+}$ potentials.

In summary, dynamic two-way signal traffic along the apical dendrites of cortical pyramidal neurons is likely to occur. Thus, strong orthodromic depolarizing synaptic inputs can activate dendritic $\mathrm{Na}^{+}$spikes, which trigger dendritic high-voltage-activated $\mathrm{Ca}^{2+}$ potentials to "amplify" locally the propagation of synaptic signals en route to the soma, thus providing a local 


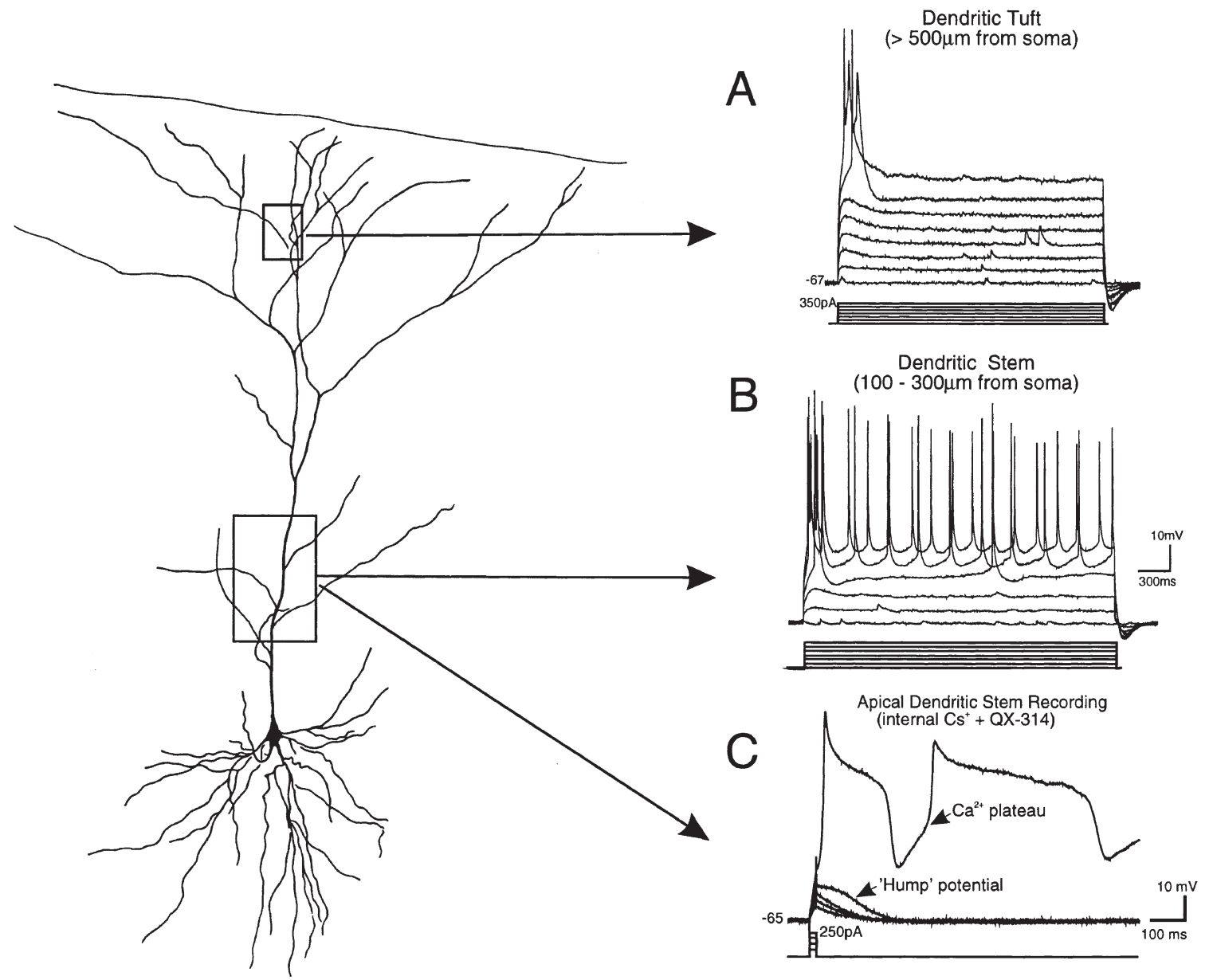

Figure 4. Apical dendritic recordings from pyramidal PFC neurons showing distinct firing patterns in response to injection of depolarizing current pulses; (left): camera lucida drawing of a biocytin-stained PFC pyramidal neuron. Square boxes show the dendritic regions where patch clamp recordings were made; (right): (A) recordings made in dendritic tuft branches over $600 \mu \mathrm{m}$ from the soma. Evoked spike firing was limited to single spike or a doublet; (B) apical dendritic stem recording showing repetitive firing in response to current pulses; (C) dendritic stem recording following blockade of $\mathrm{Na}^{+}$and $\mathrm{K}^{+}$currents by TTX and TEA. Intradendritic current injection evoked a "hump" potential and large high-voltage-activated regenerative $\mathrm{Ca}^{2+}$ plateau of $>100 \mathrm{~ms}$ duration.

mechanism for regenerative spike firing, and to trigger spike bursts. When $\mathrm{Na}^{+}$spikes are initiated in the axosomatic regions, they can backpropagate to the apical dendrites. These backpropagating $\mathrm{Na}^{+}$spikes can induce a large influx of $\mathrm{Ca}^{2+}$ into the apical dendrite, which, when closely paired with the arrival of afferent synaptic inputs, can induce long-term Hebbian/associative forms of synaptic plasticity (Markram et al. 1997a; Magee and Johnston 1997). Conceivably, neuromodulation of dendritic $\mathrm{Na}^{+}$, or $\mathrm{Ca}^{2+}$ (as well as $\mathrm{K}^{+}$), channel activities in the apical dendrites by transmitters or neuromodulators will profoundly alter the dynamic two-way trafficking of signals along the dendrites of cortical neurons (Chen and Lambert 1997; Kavalali et al. 1997a; Jones and Elmslie 1997) (Figure 5).

\section{Dopamine Modulation of Dendritic High-Voltage-Activated $\mathrm{Ca}^{2+}$ Spike Potentials}

Dopamine has been shown to modulate high-voltageactivated $\mathrm{Ca}^{2+}$ currents in several types of vertebrate and invertebrate neurons in vitro (Paupardin-Tritsch et al. 1985; Marchetti et al. 1986; Williams et al. 1990; Surmeier et al. 1995; Hernández-López et al. 1997). In rat PFC pyramidal layer V-VI neurons, following blockade of $\mathrm{Na}^{+}$and $\mathrm{K}^{+}$channels, multiphasic high-voltage-activated $\mathrm{Ca}^{2+}$ potentials evoked by intracellular depolarizing pulses consist of "hump," spikes (>50 ms) and plateau ( $>100 \mathrm{~ms}$ ) (Seamans et al. 1997). Such multiphasic dendritic $\mathrm{Ca}^{2+}$ potentials may reflect multiple somadendritic sites of electrogenesis (Reuveni et al. 1993) (Figure 4C). 
Under current-clamp conditions, direct D1/5 receptor stimulation (by SKF38393, SKF 81297 or A77656) induced three forms of modulation. First, in some PFC pyramidal neurons, a dihydropyridine-sensitive dendritic $\mathrm{Ca}^{2+}{ }_{-}$"hump" potential is augmented by D1/5 receptor activation (Yang et al. 1998), suggesting that dopamine may augment the L-type $\mathrm{Ca}^{2+}$ current mediated "hump" potential. Second, in other pyramidal neurons, the amplitude of high-voltage-activated $\mathrm{Ca}^{2+}$ spikes evoked by intracellular injections of current pulses were suppressed. Similar suppression of the $\mathrm{Ca}^{2+}$ spike amplitude can also be observed following applications of $\mathrm{N}$-type $\mathrm{Ca}^{2+}$ channel antagonist $\omega$-conotoxin GVIA (Yang et al. 1996b, 1998). Third, in some other PFC pyramidal neurons, the repolarizing shoulder of the dendritic high-voltage-activated $\mathrm{Ca}^{2+}$ plateau ( $>100 \mathrm{~ms}$ duration), as well as the depolarizing afterpotential that follows the $\mathrm{Ca}^{2+}$ spike (Haj-Dahmane and Andrade 1997) were significantly broadened by D1/5 agonists. This latter action of the D1/5 agonist changed the $\mathrm{Ca}^{2+}$ spike to a $\mathrm{Ca}^{2+}$ plateau potential (Yang et al. 1998). Subsequent application of the L-type $\mathrm{Ca}^{2+}$ channel antagonist nimodipine markedly supressed this augmentation of the duration of the $\mathrm{Ca}^{2+}$ plateau, suggesting that $\mathrm{D} 1 / 5$ receptor stimulation augmented this L-type $\mathrm{Ca}^{2+}$ channel-mediated $\mathrm{Ca}^{2+}$ potential.

The suppression of the amplitude of the N-type $\mathrm{Ca}^{2+}$ currrent by dopamine or its D1/5 agonist has been shown in striatal and sympathetic neurons (Surmeier et al. 1995; Formenti et al. 1998). On the other hand, the enhancement of a L-type $\mathrm{Ca}^{2+}$ conductance following $\mathrm{D} 1 / 5$ receptor activation is consistent with the results from several recent studies in striatal (Galarraga et al. 1997; Hernández-López et al. 1997) and retinal horizontal cells (Pfeiffer-Linn and Lasater 1996). In hippocampal neurons and bovine chromaffin cells, single channel recordings have shown that cAMP analog, or dopamine and its D1/5 agonist, increase the availability of L-type channels. This process is attributed to a recruitment of previously "silent" L-type $\mathrm{Ca}^{2+}$ channels so that there is a reopening of these channels, particularly during repolarization from a moderate depolarization (Artalejo et al. 1990; Kavalali et al. 1997b). In current-clamp dendritic recordings, this mechanism may be responsible for the enhancement of the duration of high-voltageactivated dendritic $\mathrm{Ca}^{2+}$ spikes by $\mathrm{D} 1 / 5$ receptor activation (Yang et al. 1998).

Although a voltage-clamp analysis of the isolated $\mathrm{Ca}^{2+}$ currents modulated by dopamine is necessary to characterize these effects, such an analysis is very difficult. This is because many of the $\mathrm{Ca}^{2+}$ potentials are generated in multiple compartments in a single neuron, and they are often inadequately clamped under wholecell recording mode recorded in the soma or in the dendrites. Nevertheless, current-clamp data suggest that D1/5 receptor stimulation can modulate the amplitude
(N-type channel mediated), as well as the duration (L-type channel mediated), of dendritic $\mathrm{Ca}^{2+}$ potentials (Yang et al. 1998).

\section{Functional Roles of Dopamine Modulation of Dendritic $\mathrm{Ca}^{2+}$ Potentials in Synaptic Integration of Pyramidal PFC Neurons}

Synpatic activation of dendrites can lead to depolarization of regions of the dendritic tree, which then activate local dendritic high-voltage-activated $\mathrm{Ca}^{2+}$ channels to mediate the "hump" potential, $\mathrm{Ca}^{2+}$ spikes, and plateau potentials. The depolarizing $\mathrm{Ca}^{2+}$ "hump" potential (together with the $\mathrm{I}_{\mathrm{NaP}}$ activated at the subthreshold voltage range) can also serve to relieve the voltage-dependent $\mathrm{Mg}^{2+}$ block of the dendritic NMDA receptor channel complex, thus allowing additional $\mathrm{Ca}^{2+}$ entry. Elevation of $\left[\mathrm{Ca}^{2+}\right]_{\mathrm{i}}$ has been shown to activate diverse intracellular biochemical processes responsible for altering synaptic efficacy (Hirsch and Crépel 1990, 1991, 1992a, 1992b; Regehr and Tank 1990; Sah and Nicoll 1991; Alford et al. 1993; Perkel et al. 1993; Ghosh and Greenberg 1995).

Dendritic high-voltage-activated $\mathrm{Ca}^{2+}$ spikes and plateau potentials are likely to participate in multiple functions that are important for burst firing mechanisms, sustaining repetitive firing, and enduring forms of changes in synaptic plasticity (Figure 5). Moderate attenuating effects on the amplitude of the dendritic $\mathrm{Ca}^{2+}$ spikes following D1/5 receptor activation may "focus" or "sharpen" the effects of suprathreshold inputs arising primarily from different cortical association areas. Strong suppressive actions of dopamine on the N-type channel mediated dendritic $\mathrm{Ca}^{2+}$ spikes may functionally uncouple the major input zones (in the apical dendritic arbors in layers I-II) from the soma-basal dendritic compartments of layer V-VI pyramidal PFC neuron (Yang and Seamans 1996). This latter action may help to explain in part why dopamine has often been attributed as having an "inhibitory" or "suppressive" effect on spontaneous firing or activities evoked by specific inputs in the PFC.

The actions of dopamine on N-type high-voltageactivated $\mathrm{Ca}^{2+}$ spike potentials may also spatially restrict $\mathrm{Ca}^{2+}$-dependent events in the dendrites. If this reduction was sufficiently strong, only very strong suprathreshold synaptic inputs might activate local N-type channels. This reduction of dendritic $\mathrm{Ca}^{2+}$ influx should result in a reduced $\mathrm{Ca}^{2+}$ influx in various dendritic regions. Because it has been hypothesized that lower $\left[\mathrm{Ca}^{2+}\right]_{\mathrm{i}}$ may be a prerequisite for long-term depression (LTD) to occur (Bear and Malenka 1994; Lisman 1994), the dopamine modulation of the high-voltage-activated $\mathrm{Ca}^{2+}$ channels in PFC neurons may favor and facilitate LTD over LTP induction (Law-Tho et al. 1994; Otani et al. 1998). $\left[\mathrm{Ca}^{2+}\right]_{\mathrm{i}}$-dependent LTP or LTD 


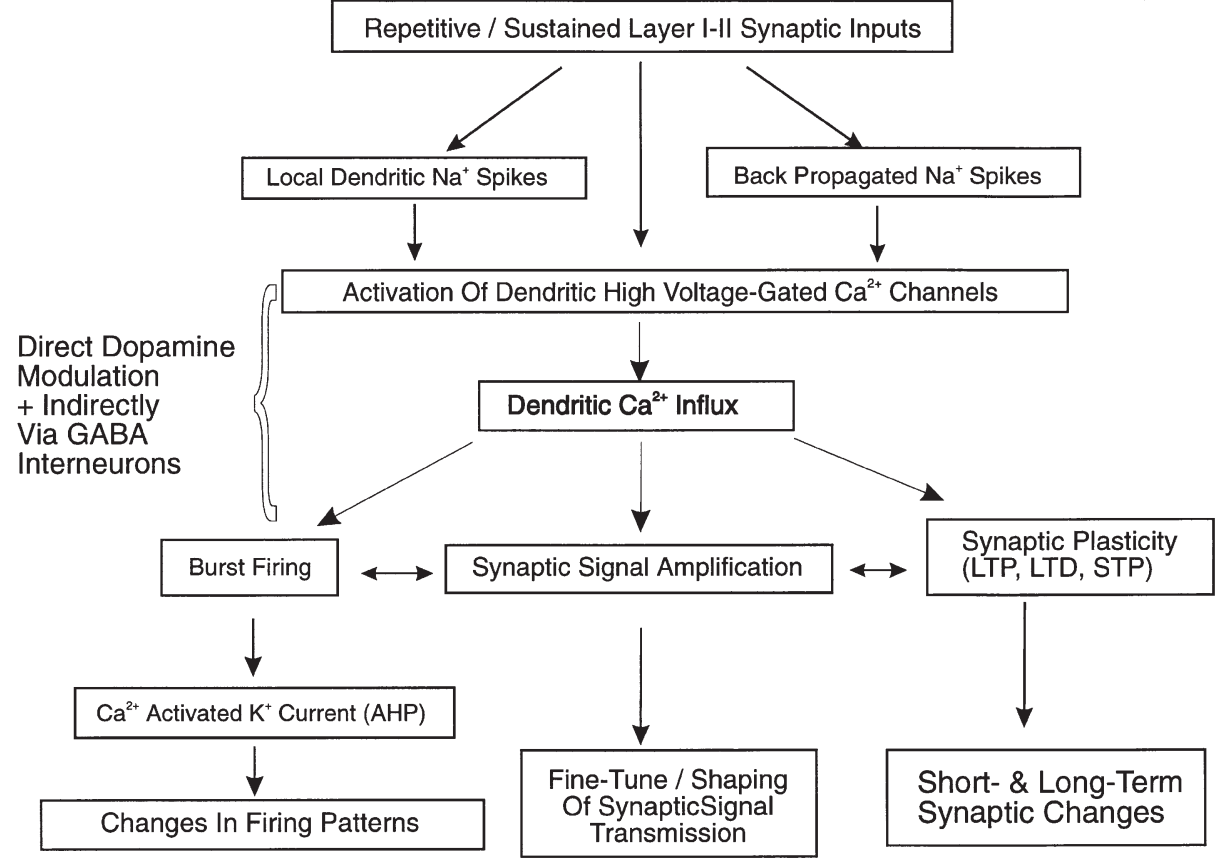

Figure 5. A schematic summarizing the physiological roles of high threshold $\mathrm{Ca}^{2+}$ "hump" and spike potentials and their interactions with dopamine. frequently lasts from tens of minutes to hours and, thus, is less likely to directly contribute to the short-term working memory mechanisms typically processed by the PFC (Goldman-Rakic et al. 1990). However, such long-term changes in synaptic weights could set up the local network to be more responsive to certain types of inputs or to be more or less likely to be recurrently active during a working memory task. Whether shortterm (lasting for seconds or minutes only) synaptic changes in PFC neurons contribute to short-term working memory mechanisms has not been explored adequately.

On the other hand, the augmentation of the duration of L-type $\mathrm{Ca}^{2+}$ channel-mediated $\mathrm{Ca}^{2+}$ plateau by dopamine may complement the dopamine-mediated augmentation of the effects of the $\mathrm{I}_{\mathrm{NaP}}$ and cause PFC neurons to fire in sustained spike train. D1/5 receptor activation also augments the duration of L-type-mediated $\mathrm{Ca}^{2+}$ spikes in striatal neurons (Hernández-López et al. 1997). When striatal neurons are held at depolarized membrane potentials, the voltage-dependent modulation of the L-type $\mathrm{Ca}^{2+}$ spike duration by dopamine or D1/5 agonists increases the excitability of the neuron to NMDA application and to intracellular depolarizing pulse injections (Cépeda et al. 1998; Galarraga et al. 1997; Hernández-López et al. 1997). Because L-type $\mathrm{Ca}^{2+}$ channels and NMDA receptors enable large influx of cationic currents at depolarized potentials, the modulation of these currents by DA may allow PFC neurons to be more responsive to excitatory inputs when they are in a depolarized state. The application of the new technique of differential interference contrast-infrared videomicroscopy to visualize PFC neuronal dendrites for patch-clamp recording (MacVicar 1984; Stuart et al. 1993; Dodt and Zieglgansberger 1994; Stuart and Spruston 1995), coupled with imaging of changes in cellular $\mathrm{Ca}^{2+}$ fluxes, will provide important clues to enable a better understanding of the mechanisms of D1/5 receptor modulation of dendritic $\mathrm{Ca}^{2+}$ dynamics and their contribution to electrophysiological signal processing in PFC neurons.

\section{Interactions Of GABAergic Interneurons with Pyramidal Neurons in the PFC}

Another major transmitter system that regulates the excitability of layer V-VI PFC pyramidal neurons comprises intrinsic GABAergic interneurons. Simultaneous extracellular recordings of pyramidal/putative GABAergic interneruon cell pairs in the PFC of behaving primates performing an oculomotor saccade response task to visual stimuli have been attempted recently (Wilson et al. 1994). The study showed that the activity pattern of the two cell types oppose each other. Hence, the heightened firing of the interneurons was coupled with reduced firing of pyramidal neurons. This suggests that the GABAergic interneuron has a role in shaping the firing pattern of PFC neurons in encoding such visual responses (Wilson et al. 1994).

Combined electrophysiology and morphological analyses at the light microscopic level have shown that diverse types of GABAergic interneurons have extensive axonal arbors, with their ascending and descending axons and collaterals straddling different layers of the rat frontal cortex (Kawaguchi 1993, 1995; Kawaguchi and Kubota 1995, 1996). Judging by their anatomical 
arrangements, GABAergic interneurons can exert a broad range of functional influences on PFC signal processing via their actions on different soma-dendritic compartments of the pyramidal cell (see below).

\section{Actions of GABA Interneurons on PFC Pyramidal Neurons}

GABA is known to exert its hyperpolarizing action in the perisomatic region of neurons to suppress spike generation. Recently, GABA has also been shown to exert a compartmental modulation of soma and dendrites in single hippocampal pyramidal neurons (Buhl et al. 1994; Kim et al. 1995; Miles et al. 1996). In the dendrites, GABAergic inhibitory postsynaptic potentials (IPSPs) may serve the following functions. First, They may temporarily hyperpolarize pyramidal cells to de- inactivate dendritic voltage-sensitive channels, such as low threshold T-type $\mathrm{Ca}^{2+}$ channels. Recent evidence suggests that activation of T- channels "amplifies" local subthreshold synaptic input to a small region of the dendrite (Callaway et al. 1995; Magee and Johnston 1995a, 1995b; de la Pena and Geijo-Barrientos 1996; Gillessen and Alzheimer 1997). Thus, this GABAergic action may "prime" local dendritic regions for subsequent depolarizing inputs. Furthermore, during active background neuronal firing, many voltage-dependent currents are inactivated in the depolarized state. These currents must be reactivated by varying periods of hyperpolarization. GABAergic hyperpolarzation may serve this very important role in controlling neuronal excitability. Second, they may alter the timing of onset and kinetics of activation of the dendritic high-voltageactivated $\mathrm{Ca}^{2+}$ channels that can be activated by synaptic inputs or by backpropagated spikes (Callaway et al. 1995; Miles et al. 1996; Tsubokawa and Ross 1996; Miura et al. 1997). Third, they may hyperpolarize dendritic membranes and shunt strong depolarizing inputs. This hyperpolarization can promote voltage-dependent $\mathrm{Mg}^{2+}$ block of NMDA receptors, and, thereby, reduce the probability of those synapses undergoing changes in synaptic plasticity (Kanter et al. 1996).

All these actions of GABA on pyramidal dendrites and soma could presumably be regulated indirectly by dopamine via its actions on GABAergic interneurons to fine tune voltage-dependent processes in the soma-dendritic axis.

\section{Dopamine Interaction with GABAergic Interneurons in PFC}

The relationship of mesocortical dopamine inputs with local GABAergic interneurons is intriguing. Mesocortical dopamine projections terminate on dendrites, soma, and from terminals of GABAergic nonpyramidal inter- neurons that synaptically contact pyramidal neurons in the PFC. Most of the dopamine terminals form no synaptic specialization on these cellular elements of GABAergic interneurons (van Eden et al. 1987; Séguéla et al. 1988; Goldman-Rakic et al. 1989; Verney et al. 1990; Benes et al. 1993; Smiley and Goldman-Rakic 1993; Sesack et al. 1995). Both D1 and D4 receptor immunoreactivity have recently been found in parvalbumin-containing GABAergic interneurons in monkey PFC (Mrzijak et al. 1996; Muly et al. 1997). Conceivably, dopamine may directly interact with the apical and the proximal dendrites of deep layer pyramidal output cells, as well as indirectly influence pyramidal cells via D1 or D4 receptor actions on intrinsic GABAergic interneurons. Indeed, much of the so-called "inhibitory" actions of dopamine may be mediated by way of GABAergic interneurons (Pirot et al. 1992).

The electrophysiological mechanisms of dopamine on PFC GABAergic interneurons remain unclear at present. Bath application of dopamine at high concentrations $(0.4 \mathrm{~mm})$ in the presence of a dopamine uptake blocker increases bicuculline-sensitive IPSPs in pyramidal neurons sampled in layers III, V, and VI of rat PFC slices (Penit-Soria et al. 1987). This suggests that dopamine activates GABAergic interneurons synapsing onto PFC pyramidal neurons. Biochemical evidence analyzing GABA release from PFC slices indicates that nanomolar concentrations of D2/3/4 agonists (quinpirole, lisuride, and RU24926) induce a $<30 \%$ increase in spontaneous release of preloaded, radiolabeled GABA; whereas, electrically evoked release is suppressed by the same agonists (Rétaux et al. 1991).

A particular subpopulation of PFC interneurons within layer V-VI express mRNA that encode for a large isoform of the enzyme for GABA synthesis, glutamic acid decarboxylase $\left(\mathrm{GAD}_{67}\right)$. Following electrolytic or neurotoxic (6 OHDA) lesions of the VTA DA neurons, activity-dependent expression of the mRNA is suppressed (Lidefors et al. 1989; Rétaux et al. 1994). This further suggests that specific population of PFC GABAergic interneurons is functionally regulated by dopamine.

Recently, direct actions of dopamine on PFC interneurons have been studied using patch-clamp recordings under visual guidance with differential interference contrast/infrared videomicroscopy (Yang et al. 1997a; Zhang et al. 1997). Four types of small interneurons have been characterized by Kawaguchi and coworkers (Kawaguchi 1993, 1995; Kawaguchi and Kubota 1995, 1996). They are fast-spiking, low-threshold spike, late-spiking, and regular spiking nonpyramidal neurons. In the presence of TTX, which blocks all synaptic inputs, dopamine was found to depolarize reversibly only fast-spiking interneurons (Yang et al. 1997a; Zhang et al. 1997). D1/5 receptor agonists (SKF81297, SKF38393) induced a small (1-3 $\mathrm{mV})$, but prolonged, membrane 
depolarization that outlasted the short period of application. The D2/3/4 agonist quinpirole failed to alter membrane potential by itself, but it induced hyperpolarization only when the neuron was already depolarized by dopamine or D1/5 agonists (Gorelova and Yang 1998). The interactions of the D1/5 and D2/3/4 receptors may shape the duration of the dopamineinduced membrane depolarization in fast-spiking GABAergic interneurons in the PFC.

\section{Functional Roles of Dopamine-ABA Interactions in Pyramidal PFC Neurons}

Synaptic GABA release induced by dopamine may also modulate signal integration in individual deep layer V-VI PFC pyramidal output neurons. In the perisomatic region of pyramidal neurons, near the axon-hillock, several potential mechanisms may exist. First, dopamine activation of GABAergic inputs lead to GABA-mediated IPSPs that may suppress spike initiation mechanisms, as supported by ultrastructural evidence (Sesack et al. 1995). This mechanism may account for the main "inhibitory" actions of dopamine on spontaneous firing in the PFC (Pirot et al. 1992, 1994). Second, dopamine activation of GABAergic interneurons that innervate the perisomatic region of pyramidal neurons may synchronize firing patterns to phase-lock activity with interneurons (Cobb et al. 1995; Whittington et al. 1995). The intrinsic subthreshold membrane oscillations of PFC pyramidal neurons, mediated by a $\mathrm{I}_{\mathrm{NaP}}$ (Llinas et al. 1991; Yang et al. 1996a), may provide a supporting mechanism for synchronization when tuned to the same frequency entrained by the interneruon (Amitai 1994; Jeffreys et al. 1996; Gutfreund et al. 1995; Lampl and Yarom 1993).

It has been hypothesized that membrane oscillations can functionally synchronize the activity of a given network of neurons, thus ensuring that neuronal groups that resonate at the same frequency will fire in synchrony. A common mode of oscillation shared by cortical neurons from adjacent columns (often connected by horizontally projecting axons) could constitute a synchronizing mechanism by which the activity patterns of other multiple inputs are coordinated (Alonso and Klink 1993; Engel et al. 1992; Lampl and Yarom 1993; Singer 1993; Singer and Gray 1995; König et al. 1996; König and Engel 1995). Unfortunately, the action of dopamine on such synchronizing mechanisms has not been explored. Third, dopamine increases the frequency of spontaneous GABA-mediated IPSPs. These IPSPs can interpose between repetitive spike firing and may either decrease the over-all mean firing rate of pyramidal neuron or restructure the firing pattern without changing mean firing rate. Indeed, simultaneous multi-unit recordings from PFC or cortical neurons of monkey performing some memory tasks have shown the coding is accomplished by a restructuring of firing patterns without changing the over-all mean firing rate (Abeles et al. 1993; Vaadia et al. 1995; de Charms and Merzenich 1996). Finally, the current electrophysiological understanding of dopamine actions suggests that it is neither "excitory" nor "inhibitory" on pyramidal PFC neurons. Rather, the actions of dopamine are dependent on the foci, timing, and strength of synaptic inputs, as well as the membrane potential range at which PFC neurons are operating at a given moment. In other words, the actions of dopamine in the PFC are internal state dependent.

\section{Synthesis of A Neuronal Model of Schizophrenia Based on The Electrophysiological Actions of Dopamine}

Based on the available electrophysiological results regarding dopamine actions on PFC neurons, we propose a model that may account for several key aspects of schizophrenia pathophysiology. Figure 6A illustrates a highly simplified version of a basic signal computational/processing unit, which consists of a layer V-VI PFC pyramidal neuron projecting to the NAc (mesolimbic dopamine neuron terminal fields) or to the VTA (the origins of the mesocortical and mesolimbic dopamine systems) and a GABAergic interneuron (see Figure 1). The pyramdial neuron receives functionally segregated inputs in its apical dendrites and basal dendrites from diverse cortical and subcortical regions (see Table 1). The GABAergic interneuron exerts tonic hyperpolarizing action in the apical dendrites, as well as in the somatic region of the pyramidal cell (Soltesz et al. 1995; Miles et al. 1996; Kim et al. 1995). The modulatory inputs to the pyramidal dendrite by the GABAergic interneurons can, in turn, be regulated by mesocortical dopamine inputs to these interneurons.

Under Normal Conditions (Figure 6A). Dopamine activates $\mathrm{D} 1 / 5$ receptors on pyramidal dendrites to attenuate directly the amplitude or to augment the duration of dendritic high-voltage-activated $\mathrm{Ca}^{2+}$ spikes and plateau, respectively. Dopamine also modulates dendritic $\mathrm{N}$-type $\mathrm{Ca}^{2+}$ channels directly or indirectly via the actions of dopamine on GABA interneurons. A moderate dopamine suppression of $\mathrm{N}$-type $\mathrm{Ca}^{2+}$ channels may "sharpen" incoming depolarizing synaptic signals (from layer I-II inputs) arriving at the distal dendrite and en route to the soma. Large suppression of N-type $\mathrm{Ca}^{2+}$ channels may "uncouple" the dendrites, preventing distal signals from reaching the soma. Hence, the shaping of these synaptic signals may be dependent on the degree of attenuation of the dendritic N-type $\mathrm{Ca}^{2+}$ potential (Figure 6A).

When soma-dendritic L-type $\mathrm{Ca}^{2+}$ channels are modulated by dopamine, a dendritic "hump" potential is 

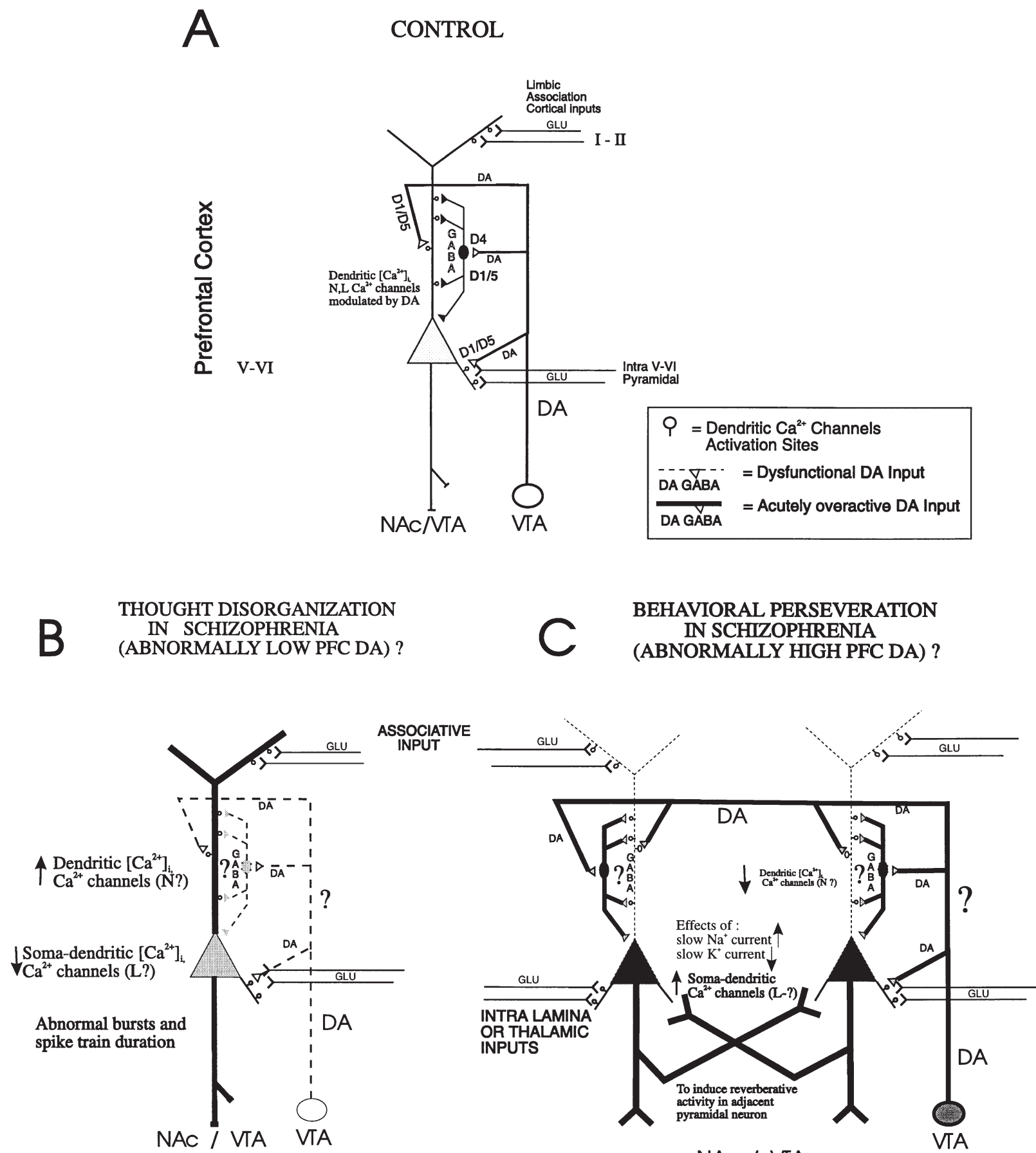

NAc / VTA

Figure 6. A PFC neuronal model of the pathophysiology of schizophrenia (see text for details).

augmented and amplifies subthreshold synaptic inputs. Furthermore, when the duration of soma-dendritic $\mathrm{Ca}^{2+}$ plateau is augmented by dopamine, the $\mathrm{Ca}^{2+}$ plateau can now trigger spike firing and support sustained repetitive firing in response to depolarizing synaptic inputs.

On the other hand, depolarizing signals arriving from neighboring deep layer pyramidal neurons via their axonal collaterals (intralaminar inputs) (Lewis and
Anderson 1995; Pucak et al. 1996) to the somatic/basal dendritic compartment may be augmented by the postsynaptic actions of $\mathrm{D} 1 / 5$ receptors that modulate $\mathrm{I}_{\mathrm{NaP}}$ and the slowly inactivating $\mathrm{K}^{+}$current located near these compartments. In addition, D1/5 or D4 receptors found in GABAergic interneurons (Mrzijak et al. 1996; Yang et al. 1998) may play a role in activating the GABA interneuron. GABAergic IPSPs elicited by dopa- 
mine can, in turn, suppress voltage-sensitive dendritic $\mathrm{Ca}^{2+}$ potenitals (Figure $6 \mathrm{~A}$ ).

Possible Mechanisms Underlying Thought Disorganization (Figure 6B). Systemic administration of amphetamine or apomorphine augments local cerebral blood flow in the PFC of drug-free chronic schizophrenics. In some of these cases, such treatment resulted in an improvement in cognitive task performance (Daniel et al. 1989, 1991; Dolan et al. 1995; Fletcher et al. 1996; Mattay et al. 1996). This indirect evidence suggests a dysfunctional mesocortical dopamine input to the PFC, perhaps both at the presynaptic (terminal release mechanism) and at the postsynaptic (receptor) level. Consistent with this suggestion are postmortem findings indicating a loss of functional mesocortical dopaminergic inputs to the PFC of schizophrenic brains (Akil and Lewis 1996), and a significant change in the binding kinetics of D1/5 binding sites, as shown in the positron emission tomography (PET) images of PFC from drug-naive or drug-free schizophrenics (Okubo et al. 1997). If both of these findings are replicable, then they suggests that a loss of mesocortical dopamine input may paradoxically lead to a reduction (rather than a classically predictable increase) of D1/5 receptor sites in PFC. Furthermore, a loss of intrinsic GABAergic interneurons and/or a reduction of GAD mRNA in PFC of subgroups of schizophrenics has also been reported (Benes et al. 1991, 1992, 1993; Akbarian et al. 1995). Hence, a loss of dopaminergic and/or GABAergic regulation of PFC pyramidal neurons may coexist in subtypes of schizophrenia.

A combined loss of the normal GABAergic and mesocortical dopamine function in schizophrenia may have serious consequences for normal signal processing in PFC pyramidal neurons. The model in Figure 6B postulates that under this condition, limbic/association transcortical inputs will be integrated abnormally because of nonspecific activation of poorly modulated dendritic N-type voltage-gated $\mathrm{Ca}^{2+}$ channels. This may result in abnormal forms of spike burst outputs from PFC pyramidal neurons. The nonspecific activation of PFC can disrupt normal signal processing carried out in the PFC and result in distractibility, and this may account for attentional deficits in schizophrenics. This behavioral manifestation can be exhibited primarily as an inability to disregard irrelevant information, while ignoring relevant details in a given situation (Posner et al. 1988; Saykin et al. 1991; Frith 1992; Park and Holzman 1993).

A loss of mesocortical dopamine inputs may also lead to failure of modulation of synaptic signal duration that are normally amplified by soma-dendritic L-type $\mathrm{Ca}^{2+}$ channels (see above). Thus, when the duration of a given train of depolarizing inputs failed to be augmented by dendritic L-type $\mathrm{Ca}^{2+}$ channels as the signals propagate en route to the soma, a dramatic diminishment in the duration or strength of the input signals can result. The soma may fail to integrate the temporal duration of the signal and can fail to generate correct output spike trains for the given inputs arriving at the dendrite. When combined with the nonspecific overamplification of other associative signals by dendritic N-type $\mathrm{Ca}^{2+}$ channels, an abnormal pattern of active firing from PFC neurons for a given train of inputs may lead to erroneous signal encoding in the PFC. This process may underlie the cellular bases of thought disorganization. This is consistent with the PET findings of an abnormal elevation of regional cerebral blood flow in the right medial PFC, right anterior cingulate cortex, and the medial dorsal thalamus in schizophrenic patients suffering from thought disorganization (Liddle et al. 1992; Ebmeier et al. 1993) (see next section).

With a reduction or absence of dopaminergic and GABAergic dendritic modulation, the abnormal signaling in PFC output neurons can be transmitted to the NAc and VTA. In turn, an abnormal rise in NAc dopamine may result. This is consistent with some recent in vivo evidence that show that following 6 OHDA depletion of PFC dopamine, basal dopamine in the NAc remains unchanged, but dopamine release in the NAc is significantly potentiated by tail-pinch stress (King et al. 1997), foot-shock stress (Deutch et al. 1990), as well as by behaviorally reinforcing stimuli, such as palatable food or sex-related olfactory cues (Mitchell and Gratton 1992). These data suggest that following PFC DA depletion, a given external challenge (as a given normal sensory input) can result in a reactive increase of NAc dopamine (Grace 1993; Deutch 1993).

Blockade of $\mathrm{GABA}_{\mathrm{A}}$ receptors by bicuculline infusion locally in the PFC also leads to a large increase of dopamine in the NAc (Karreman and Moghaddam 1996). Local infusion of ionotropic glutamate receptor antagonists into the VTA, but not into the striatum, blocked this PFC bicuculline-induced increase in NAc dopamine level. These data place a special emphasis on the PFC $\rightarrow$ VTA pathway in mediating PFC regulation of subcortical dopamine levels (Murase et al. 1993; Taber et al. 1995). Conceivably, thought disorganization in schizophrenia may be the result of an absence of dopaminergic and GABAergic modulation of dendritic $\mathrm{Ca}^{2+}$ channels in the pyramidal neurons, resulting in a generation of "untuned" signals from the PFC neurons. Because these signals are transmitted via the PFC $\rightarrow$ VTA and PFC $\rightarrow$ NAc pathways, a reactive increase in NAc dopamine could contribute to the genesis of the associated psychotic symptoms.

Possible Mechanisms Underlying Behavioral Perseveration or Stereotypy (Figure 6C). In schizophrenics with intact mesocortical dopamine input and interneuron activity, psychotic episodes or severe stress may be 
accompanied by hyperactivity of the mesocortical dopamine input. This can result in abnormally high levels of extracellular dopamine in the PFC, as shown in laboratory animals under acute stress (Abercrombie et al. 1989; Deutch and Roth 1990; Jedema and Moghaddam 1994; Murphy et al. 1996). Under this condition, dopamine may activate the intrinsic GABAergic interneuronal network in the PFC (Benes 1997). The hyperpolarizing actions of dopamine-activated GABAergic inputs could, in turn, inactivate all voltage-dependent currents in the apical dendrite region of pyramidal neurons, including the $\mathrm{Ca}^{2+}$ and $\mathrm{Na}^{+}$currents that are functionally responsible for "amplifying" synaptic signals en route to the deep layer soma of the layer V-VI pyramidal neurons (Seamans et al. 1997; Stuart and Sakmann 1995; Schwindt and Crill 1995).

Near the somatic/basal or proximal dendritic compartments of the pyramidal PFC neuron, the postsynaptic effects of D1/5 receptor activation on the $\mathrm{I}_{\mathrm{NaP}}$ and the slowly inactivating $\mathrm{K}^{+}$currents may enhance excitability of pyramidal neurons in response to depolarizing inputs, perhaps from neighboring neurons via axonal collateral connections (Levitt et al. 1993; Kritzer and Goldman-Rakic 1995; Lewis and Anderson 1995; Pucak et al. 1996). This can be further augmented by actions of dopamine on L-type $\mathrm{Ca}^{2+}$ channel activity in the soma-dendritic regions. If these excitatory signals are conducted via horizontally projecting axon collaterals of the pyramidal neurons to the neighboring reciprocally connected neurons, sustained repetitive firing may result. The abnormal PFC firing transmitted via its axon collaterals to adjacent pyramidal neurons may establish a local internal reverberative ensemble among these neurons (Amit 1995; Vaadia et al. 1995).

In contrast, incoming transcortical signals from layer I-II can be shunted by a high level of dopamine acting: (1) directly on dendritic N-type $\mathrm{Ca}^{2+}$ channels to "uncouple" dendritic signal transmission; and (2) indirectly by dopamine activation of GABAergic interneurons innervating the apical dendrites (Figure 6C). When combined with the above reverberative activities between neighboring neurons, this may be the potential mechanism for behavioral perseveration or stereotypy. This may provide a neuronal explanation for the inability of schizophrenics to use external signals (incoming transcortical inputs) to modify ongoing behaviors. Such mechanisms would be expected to disrupt cellular processes underlying working memory (Park and Holzman 1992; Goldman-Rakic 1991, 1994; Weinberger 1991).

At first glance, the above two mechanisms (Possible Mechanisms Underlying Thought Disorganization/Behavioral Perseveration, or Sterotypy) seem to contradict some of the brain-imaging data obtained from schizophrenics. Results from many of these imaging studies suggest that PFC regional hypoperfusion are mainly observed in chronic schizophrenics exhibiting psycho- motor poverty (with negative symptoms and a prolonged duration of illness). Hypoperfusion was found both at rest and when challenged by cognitive tasks that specifically test the functions of the PFC (e.g., Wisconsin Card Sorting Test), regardless of whether patients were drug-naive or medicated (Ingvar and Franzen 1974; Franzen and Ingvar 1975; Berman et al. 1986; Weinberger et al. 1986; Mathew et al 1988; Andreasen et al. 1992; Buchsbaum et al. 1992; Liddle et al. 1992; Wolkin et al. 1992). However, in several subgroups of schizophrenics with acute psychosis (including some who were unmedicated), investigators have detected increased PFC activity at rest, with no failure of activating PFC in cognitive tasks, such as verbal fluency and executive tasks (Chua and McKenna 1995; Ebmeier et al. 1993; Heckers et al. 1998). Such patients showed a greater activation, and a lack of inactivation, of PFC cerebral blood flow (Liddle et al. 1992; Ebmeier et al. 1993, Table 2). Thus, hypoactivation of the PFC cannot be generalized to all categories of schizophrenia (Weinberger and Berman 1996; Fletcher 1998). A more likely scenario would be that episodic PFC hyperactivity and hypoactivity coexist in schizophrenic patients during the course of the illness.

\section{A New Perspective for a Pharmacotherapy for Schizophrenia}

Several typical and atypical antipsychotic drugs (all dopamine receptor antagonists) have been shown to inhibit high-voltage-activated $\mathrm{Ca}^{2+}$ currents in cultured neurons and neuronal cell-lines, independent of dopamine receptor blockade (Gould et al. 1983; Quirion et al. 1985; Galazzi et al. 1986; Ogata et al. 1989; Fletcher et al. 1994; Sah and Bean 1994; Ito et al. 1996). In particular, atypical antipsychotics of the diphenylbutylpiperidine type (e.g., pimozide, fluspirilene, clopimozide) or its derivatives have been shown to be most effective in blocking brain L-type $\mathrm{Ca}^{2+}$ channels (Gould et al. 1983; Quirion et al. 1985; Galizzi et al. 1986). It is likely that the relief of psychotic symptoms by systemically administered typical antipsychotics is partly a result of PFC neuronal "tuning" via blockade of dendritic $\mathrm{Ca}^{2+}$ channels, as well as a reduction of the abnormally elevated dopaminergic transmission via blockade of dopamine D2 receptor in the NAc. If so, compounds that have the combined ability to simulaneously stimulate D1/5 receptors (to "tune" dendritic inputs) in the PFC (where D1/5 receptors predominate) and to block D2 receptors in the NAc (to reduce the effects of overactivation of the mesolimbic dopamine system) may constitute a possible "magic bullet" for treating thought disorganization in schizophrenia. In addition, restoring GABAergic functions in the PFC may constitute an additional pharmacotherapeutic strategy. The use of new anticonvulsant GABAergic agonists (e.g., Felbamate) or 
their derivatives may be considered as an adjunct medication (McCabe et al. 1993; Rho et al. 1994).

As predicted in the model shown in Figure $6 \mathrm{C}$, a dopamine enhancement of the effects of slow $\mathrm{Na}^{+}, \mathrm{K}^{+}$ and L-type $\mathrm{Ca}^{2+}$ channels in the soma/basal dendritic conpartment of pyramidal PFC neurons may increase the excitability of pyramidal neurons. In response to local deep layer V-VI glutamatergic synaptic inputs, local circuit reverberation between adjacent glutamatergic pyramidal neurons may result. This may be expressed as behavioral perseveration or stereotypy. Conceivably, agents that reduce abnormal presynaptic glutamate release between interacting adjacent pyramidal PFC neurons are likely to reduce behavioral perseveration or stereotypy. Group II metabotropic glutamate receptor agonist (e.g., LY354740), which can block presynaptic glutamate release, has been used recently to attenuate abnormal elevation of PFC glutamate release and the resulting behavioral stereotypy following chronic treatment of the psychostimulant phencyclidine (Moghaddam and Adams 1998).

Finally, it should be noted that this review does not mean to assert that such a complex disorder as schizophrenia is attributable to defects in only the mesocortical and mesolimbic dopamine systems. The recent success in using atypical antipsychotic drugs that have a "rich" pharmacology (e.g., risperidone and olanzapine) to provide effective treatment for both positive and negative symptoms in schizophrenia without the extrapyramidal side effects has revolutionized our understanding of the pathophysiology of schizophrenia. These clinical findings have clearly suggested that interaction of multiple defective receptor systems are involved in the complex pathophysiology of schizophrenia. Based on the high affinities of these atypical antipsychotics with several serotonin receptor subtypes, in addition to their ability to elevate PFC dopamine (Bymaster et al. 1996; Kapur and Remington 1996), it seems that a more detailed understanding of how dopamine and serotonin receptors interact in the PFC will likely yield further insights into the pathophysiology of schizophrenia (Kapur and Remington 1996). The model described above suggests that a shift in our perspective on treatment of psychosis may be needed. Such a shift may enable us to change our approach from that of a general blockade of NAc dopamine transmission to a "tuning" process upstream to correct defective signal processing in the PFC of schizophrenia.

\section{CONCLUSION}

Available electrophysiological results regarding dopamine and GABA actions on PFC neurons have permitted synthesis of a novel neuronal model of schizophrenia pathophysiology. Distractable behavior associated with schizophrenia may be caused by a combined dysfunction of dopamine and GABA modulation of dendritic functions in pyramidal neurons in the PFC. In turn, this may result in dysregulated dendritic signaling in response to extrinsic transcortical associative inputs in PFC output neurons (Figure 6B). On the other hand, abnormal elevation of PFC dopamine under conditions of acute stress may uncouple extrinsic inputs, while concomitantly enhancing internal reverberative activity among adjacent pyramidal neurons. This pathophysiological condition may account for behavioral perseveration and the inability of schizophrenics to use external signals to modify ongoing behavior (Figure 6C).

Current evidence suggests that schizophrenia is likely to be a neurodevelopmental disorder (Weinberger 1996; Karayiorgou and Gogos 1997; Lewis 1997). Progress in the field of developmental neurogenetics holds promise for potential new insights that may lead to gene therapy once specific genetic defects are identified. At present, we must be realistic about our efforts to treat schizophrenia. Current therapeutic strategies only aim at symptom control during the long course of development of the disease. The model above may serve to move basic research in the pathophysiology of schizophrenia beyond academic interests. This is because the insights gained may eventually enable us to design novel antipsychotic drugs that can specifically "tune" dysregulated signal processing in the PFC of schizophrenics.

\section{ACKNOWLEDGMENTS}

The critiques of Drs. Peter Liddle, Anthony Phillips, Charles Blaha, David Bleakman, and Darryl Schoepp on an earlier draft of the manuscript are greatly appreciated. We thank Dr. Susan Sesack of the University of Pittsburgh for providing us a synopsis of the major afferents that innervate different cortical lamina of the rat prefrontal cortex. We are grateful to the third anonymous reviewer, who spent his or her time to make extensive editorial changes to improve the flow of the text. We also thank the proofreading efforts of Mark Mulhauser, Nishi Gil, Winnie $\mathrm{Ng}$, and Julianne Dixon-Yang. This work was funded by the E.J.L.B. Foundation and the Medical Research Council of Canada. J.K.S. is a recipient of a National Science and Engineering Research Council of Canada Post-Doctoral Fellowship.

\section{REFERENCES}

Abeles M, Bagmen H, Margalit E, Vaadia E (1993): Spatiotemporal firing patterns in the frontal cortex of behaving monkey. J Neurophysiol 70:1629-1639

Abercrombie ED, Keefe KA, DiFrischia DS, Zigmond MJ (1989): Differential effect of stress on in vivo dopamine release in striatum, nucleus accumbens, and medial frontal cortex. J Neurochem 52:1655-1658 
Akbarian S, Bunney WE Jr, Potkin SG, Potkin SG, Wigal SB, Hagman JO, Sandman CA, Jones EG (1993): Altered distribution of nicotinamide adenine dinucleotide phosphate-diaphorase cells in frontal lobe of schizophrenics implies disturbances of cortical development. Arch Gen Psychiat 50:169-177

Akbarian S, Kim JJ, Potkin SG, Hagman JO, Tafazzoli A, Bunney WE Jr, Jones EG (1995): Gene expression for glutamic acid decarboxylase is reduced without loss of neurons in prefrontal cortex of schizophrenics. Arch Gen Psychiat 52:258-266

Akbarian S, Kim JJ, Potkin SG, Hetrick WP, Bunney W Jr, Jones EG (1996): Maldistribution of interstitial neurons in prefrontal white matter of the brains of schizophrenic patients. Arch Gen Psychiat 53:425-436

Akil M, Lewis DA (1996): Reduced dopamine innervation of the prefrontal cortex in schizophrenia. Soc Neurosci Abst 22:1679

Alford S, Frenguelli B, Schofield JG, Collingridge G (1993): Characterization of $\mathrm{Ca}^{2+}$ signals induced in hippocampal CA1 neurons by the synaptic activation of NMDA receptors. J Physiol (London) 469:693-716

Alonso A, Klink R (1993): Differential electroresponsiveness of stellate and pyramidal-like cells of medial entorhinal cortex layer II. J Neurophysiol 70:128-143

Alzheimer C, Schwindt PC, Crill WE (1993): Modal gating of $\mathrm{Na}^{+}$channels as a mechanism of persistent $\mathrm{Na}^{+}$current in pyramidal neurons from rat and cat sensorimotor cortex. J Neurosci 13:660-673

Amit DJ (1995): The Hebbian paradigm reintegrated: Local reverberations as internal representation. Behav Brain Sci 18:617-657

Amitai Y (1994): Membrane potential oscillations underlying firing patterns in neocortical neurons. Neuroscience 63:151-161

Amitai Y, Friedman A, Connors BW, Gutnick MJ (1993): Regenerative activity in apical dendrites of pyramidal cells in neocortex. Cereb Cortex 3:26-38

Andreasen NC, Rezai K, Alliger R, Swayze VW, Flaum M, Kirchner P, Cohen G, O'Leary DS (1992): Hypofrontality in neuroleptic-naive patients and in patients with chronic schizophrenia: Assessment with Xenon 133 single-photon emission computed tomography and the tower of London. Arch Gen Psychiat 49:943-958

Andreasen NC (1997): Linking mind and brain in the study of mental illnesses: A project for a scientific psychopathology. Science 275:1586-1593

Ariano MA, Wang J, Noblett K, Larson ER, Sibley DR (1997): Cellular distribution of the rat D4 dopamine receptor protein in the CNS using antireceptor antisera. Brain Res 752:26-34

Artalejo CR, Ariano MA, Perlman RL, Fox AP (1990): Activation of facilitation calcium channels in chromaffin cells by D1 dopamine receptors through a cAMP/protein kinase A-dependent mechanism. Nature 348:239242

Astman N, Gutnick MJ, Fleidervish IA (1998): Activation of protein kinase $C$ increases neuronal excitability by regulating persistent $\mathrm{Na}^{+}$current in mouse neocortical slices. J Neurophysiol 80:1547-1551

Bacon SJ, Headlam AJ, Gabbot PL, Smith AD (1996):
Amygdala input to medial prefrontal cortex (mPFC) in the rat: A light and electron microscope study. Brain Res 720:211-219

Bassant MH, Ennouri K, Lamour Y (1990): Effects of iontophoretically applied monoamines on somatosensory cortical neurons of unanaesthetized rats. Neuroscience 39:431-439

Batuev AS, Kursina NP, Shutov AP (1990): Unit activity of the medial wall of the frontal cortex during delayed performance in rats. Behav Brain Res 41:95-102

Bear MF, Malenka RC (1994): Synaptic plasticity: LTP and LTD. Curr Opinion Neurobiol 4:389-399

Benes FM (1993): Neurobiological investigations in cingulate cortex of schizophrenia. Schizo Bull 19:537-549

Benes FM (1997): The role of stress and dopamine-GABA interactions in the vulnerability for schizophrenia. J Psychiat Res 31:257-275

Benes FM, McSparren J, Bird ED, SanGiovanni JP, Vincent SL (1991): Deficits in small interneurons in prefrontal and cingulate cortices of schizophrenic and schizoaffective patients. Arch Gen Psychiat 48:996-1001

Benes FM, Vincent SL, Alsterberg G, Bird ED, San Giovanni

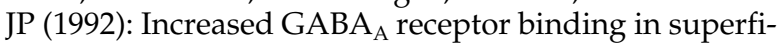
cial layers of cingulate cortex in schizophrenics. J Neurosci 12:924-929

Benes FM, Vincent SL, Molloy R (1993): Dopamine-immunoreactive axon varicosities form nonrandom contacts with GABA-immunoreactive neurons of rat medial prefrontal cortex. Synapse 15:285-295

Berendse HW, Galis-de Graaf Y, Groenewegen HJ (1992a): Topographical organization and relationship with ventral striatal compartments of prefrontal corticostriatal projections in the rat. J Comp Neurol 316:314-347

Berendse HW, Groenewegen HJ (1991): Restricted cortical termination fields of the midline and intralaminar thalmic nuclei in the rat. Neuroscience 42:73-102

Berendse HW, Groenewegen HJ, Lohman AHM (1992b): Compartmental distrbution of ventral striatal neurons projecting to the mesencephalon in the rat. J Neurosci 12:2079-2103

Berger B, Trottier S, Verney C, Gaspar P, Alvarez C (1988): Regional and laminar distribution of the dopamine and serotonin innervation in the Macaque cerebral cortex: A radioautographic study. J Comp Neurol 273:99-119

Berger B, Gasper P, Verney C (1991): Dopaminergic innervation of the cerebral cortex: Unexpected differences between rodents and primates. Trends Neurosci 14:21-27

Bergson C, Mrzljak L, Smiley JF, Pappy M, Levenson R, Goldman-Rakic PS (1995): Regional, cellular, and subcellular variations in the distribution of D1 and D5 dopamine receptors in primate brain. J Neurosci 15:7821-7836

Berman KF, Zec RF, Weinberger DR (1986): Physiological dysfunction of dorsolateral prefrontal cortex I schizophrenia. II. Role of neuroleptic treatment, attention, and mental effort. Arch Gen Psychiat 423:126-135

Bernander Ö, Koch C, Douglas R (1994): Amplification and linearization of distal synaptic input to cortical pyramidal cells. J Neurophysiol 72:2743-2753

Bernardi G, Cherunbini E, Marciani MG, Mercuri N, Stanzione P (1982): Responses of intracellularly recorded cortical 
neurons to the iontophoretic application of dopamine. Brain Res 245:267-274

Berridge MJ (1998): Neuronal calcium signaling. Neurons 21:13-26

Björklund A, Lindvall O (1984): Dopamine-containing systems in the CNS. In Björklund A, Hökfelt T (eds), Handbook of Chemical Neuroanatomy: Classical Transmitter in The Rat. Amsterdam, Elsevier/North Holland, vol 2, pp 55-122

Bogerts B (1993): Recent advances in the neuropathology of schizophrenia. Schizo Bull 19:431-445

Bouthenet ML, Souil E, Martres MP, Sokoloff P, Giros B, Schwartz JC (1991): Localization of dopamine D3 receptor mRNA in the rat brain using in situ hybridization histochemistry: Comparison with dopamine D2 receptor mRNA. Brain Res 564:203-219

Bradshaw CM, Sheridan RD, Szabaldi E (1985): Excitatory neuronal responses to dopamine in the cerebral cortex: Involvement of D2 but not D1 dopamine response. Br J Pharmacol 86:483-490

Brown AM, Schwindt PC, Crill WE (1993): Voltage-dependence and activation kinetics of pharmacologically defined components of the high-threshold calcium current in rat neocortical neurons. J Neurophysiol 70:15301543

Brown AM, Schwindt PC, Crill WE (1994): Different voltage dependence of transient and persistent $\mathrm{Na}^{+}$currents is compatible with modal-gating hypothesis for sodium channels. J Neurophysiol 71:2562-2565

Brozowski TS, Brown RM, Rosvold HE, Goldman PS (1979): Cognitive deficits caused by regional depletion of dopamine in prefrontal cortex of Rhesus monkey. Science 205:929-932

Buchsbaum MS, Haier RJ, Potkin SG, Nuechterlein KM, Bracha HS, Katz M, Lohr J, Wu J, Lottenberg S, Jerabek PA, Trenary M, Tafalla R, Reynolds C, Bunney WE Jr (1992): Frontostriatal disorder of cerebral metabolism in never-medicated schizophrenics. Arch Gen Psychiat 49:935-942

Buhl EH, Halasy K, Somogyi P (1994): Diverse sources of hippocampal unitary inhibitory postsynaptic potentials and the number of synaptic release sites. Nature 368:823-828

Bunney BS, Aghajanian GK (1976): Dopamine and norepinephrine innervated cells in the rat prefrontal cortex: Pharmacological differentiation using microiontophoretic techniques. Life Sci 19:1783-1792

Busatto GF, Kerwin RW (1997): Perspectives on the role of serotoninergic mechanisms in the pharmacology of schizophrenia. J Psychopharmacol 11:3-12

Buzsáki G, Kandel A (1998): Somadendritic backpropagation of action potentials in cortical pyramidal cells of the awake rat. J Neurophysiol 79:1587-1591

Bymaster FP, Calligaro DO, Falcone JF, Marsh RD, Moore NA, Tye NC, Seeman P, Wong DT (1996): Radioreceptor binding profile of the atypical antipsychotic olanzapine. Neuropsychopharmacology 14:87-96

Calabresi P, Mercuri N, Stanzione P, Stefani A, Bernardi G (1987): Intracellular studies on the dopamine-induced firing inhibition of neostriatal neurons in vitro: Evidence for D1 receptor involvement. Neuroscience 20:757-771
Callaway JC, Lasser-Ross N, Ross WN (1995): IPSPs strongly inhibit climbing fiber-activated $[\mathrm{Ca}]_{\mathrm{i}}$ increases in the dendrites of cerebellar purkinje neurons. J Neurosci 15:2777-2787

Campbell CBG, Hodos W (1970): The concept of homology and the evolution of the nervous system. Brain Behav Evol 3:353-367

Camps M, Cortés R, Gueye B, Probst A, Palacios JM (1989): Dopamine receptors in human brain: Autoradiographic distribution of D2 sites. Neuroscience 28:275-290

Cantrell AR, Smith RD, Coldin AL, Scheuer T, Catterall WA (1997): Dopaminergic modulation of sodium current in hippocampal neurons via cAMP-dependent phosphorylation of specific sites in the sodium channel $\alpha$ subunit. J Neurosci 17:7330-7338

Carlson A (1995): The dopamine theory revisisted. In Hirsch SR, Weinberger DR (eds), Schizophrenia. Cambridge, MA, Blackwell, pp 379-400

Carr DB, Sesack SR (1996): Hippocampal afferents to the rat prefrontal cortex: Synaptic targets and relation to dopamine terminals. J Comp Neurol 369:1-15

Cauller LJ, Connors BW (1994): Synaptic physiology of horizontal afferents to layer I in slices of rat SI neocortex. J Neurosci 14:751-762

Cépeda C, Radisavljevic Z, Peacock W, Levine MS, Buchwald NA (1992a): Differential modulation by dopamine of responses evoked by excitatory amino acids in human cortex. Synapse 11:330-341

Cépeda C, Walsh JP, Peacock W, Buchwald NA, Levine MS (1992b): Neurophysiological, pharmacological, and morphological properties of human caudate neurons recorded in vitro. Neuroscience 59:89-103

Cépeda C, Chandler SH, Shumate LW, Levine MS (1995): Persistent $\mathrm{Na}^{+}$conductance in medium-sized neostriatal neurons: Characterization using infrared videomicroscopy and whole cell patch-clamp recordings. J Neurophysiol 74:1343-1348

Cépeda C, Colwell CS, Itri JN, Chandler SH, Levine MS (1998): Dopaminergic modulation of NMDA-induced whole cell currents in neostriatal neurons in slices: Contribution of calcium conductances. J Neurophysiol 79:82-94

Chen H, Lambert NA (1997): Inhibition of dendritic calcium influx by activation of G-protein-coupled receptors in the hippocampus. J Neurophysiol 78:3484-3488

Chen WR, Midtgaard J, Shepherd GM (1997): Forward and backward propagation of dendritic impulses and their synaptic control in mitral cells. Science 278:463-467

Chua SE, McKenna PJ (1995): Schizophrenia-A brain disease? A critical review of stuctural and functional cerebral abnormality in the disorder. Br J Psychiat 166:563-582

Cobb SR, Buhl EH, Halasy K, Paulsen O, Somogyi P (1995): Synchronization of neuronal activity in hippocampus by individual GABAergic interneurons. Nature 378: 75-78

Cohen JD, Servan-Schreiber D (1993): A theory of dopamine function and its role in cognitive deficits in schizophrenia. Schizo Bull 19:85-104

Colbert CM, Johnston D (1996): Axonal action-potential initiation and $\mathrm{Na}^{+}$channel densities in the soma and axon initial segment of subicular pyramidal neurons. J Neurosci 16:6676-6686 
Condé F, Marie-Lepoivre E, Audinat E, Crépel F (1995): Afferent connections of the medial frontal cortex of the rat. II. Cortical and subcortical afferents. J Comp Neurol 352:567-593

Connors BW, Gutnick MJ, Prince DA (1982): Electrophysiological properties of neocortical neurons in vitro. J Neurophysiol 48:1302-1320

Cortés R, Gueye B, Pazos A, Probst A, Palacios JM (1989): Dopamine receptors in human brain: Autoradiographic distribution of the D1 sites. Neuroscience 28:263-273

Crill WE (1996): Persistent sodium current in mammalian central neurons. Ann Rev Physiol 58:349-362

Daniel DG, Berman KF, Weinberger DR (1989): The effects of apomorphine on regional cerebral blood flow in schizophrenia. J Neuropsychiat 1:377-384

Daniel DG, Weinberger DR, Jones DW, Zigun JR, Coppola R, Handel S, Bigelow LB, Goldberg TE, Berman KF, Kleinman JE (1991): The effect of amphetamine on regional cerebral blood flow during cognitive activation in schizophrenia. J Neurosci 11:1907-1917

Davis KL, Kahn RS, Ko G, Davidson M (1991): Dopamine in schizophrenia: A review and reconceptualization. Am J Psychiat 148:1474-1486

de la Pena E, Geijo-Barrientos E (1996): Laminar localization, morphology, and physiology properties of pyramidal neurons that have the low-threshold calcium current in guinea pig medial frontal cortex. J Neurosci 16:5301-5311

de Shutter E, Bower JM (1994): An active membrane model of the cerebellar Purkinje cell. 2. Simulation of synaptic responses. J Neurophysiol 71:375-400

de Charms RC, Merzenich MM (1996): Primary cortical representation of sounds by the coordination of actionpotential timing. Nature 381:610-613

De Keyser J, Dierckx R, Vanderheyden P, Ebinger G, Vauquelin $G$ (1988): D1 dopamine receptors in human putamen, frontal cortex, and calf retina: Differences in guanine nucleotide regulation of agonist binding and adenylate cyclase stimulation. Brain Res 443:77-84

Descarries L, LeMay B, Doucet G, Berger B (1987): Regional and laminar density of the dopamine innervation in the adult rat cerebral cortex. Neuroscience 21:807-824

Deutch AY (1993): Profrontal cortical dopamine systems and the elaboration of functional corticostriatal circuits: Implications for schizophrenia and Parkinson's disease. J Neural Transm 91:197-221

Deutch AY, Roth RH (1990): The determinants of stressinduced activation of the prefrontal cortical dopamine system. Prog Brain Res 85:367-403

Deutch AY, Clark WA, Roth RH (1990): Prefrontal cortical dopamine depletion enhances the responsiveness of mesolimbic dopamine neurons to stress. Brain Res 521:311-315

Dodt HU, Zieglgansberger W (1994): Infrared videomicroscopy: A new look at neuronal structure. Trends Neurosci 17:453-458

Dolan RJ, Fletcher P, Frith CD, Friston KJ, Frackowiak RSJ, Grasby PM (1995): Dopaminergic modulation of impaired cognitive activation in the anterior cingulate cortex in schizophrenia. Nature 378:180-182
Dumartin B, Caillé I, Gonon F, Bloch B (1998): Internalization of D1 dopamine receptor in striate neurons in vivo as evidence of activation by dopamine agonists. J Neurosci 18:1650-1661

Durstewitz D, Kelc M, Güntürkün O (1999): A neurocomputational theory of the dopaminergic modulation of working memory function. J. Neurosci 19:2807-2822

Ebmeier KP, Blackwood DHR, Murray C, Souza V, Walker M, Dougall N, Moffoot APR, O'Carroll RE, Goodwin GM (1993): Single-photon emission computed tomography with ${ }^{99 m}$ Tc-exametazime in unmedicated schizophrenic patients. Biol Psychiat 33:487-495

Engel AK, König P, Kreiter AK, Schillen TB, Singer W (1992): Temporal coding in the visual cortex: New vistas on integration in the nervous system. Trends Neurosci $15: 218-226$

Fallon JH, Moore RY (1978): Catecholamine innervation of the basal forebrain. IV. Topography of the dopamine projection to the basal forebrain and neostriatum. J Comp Neurol 218:91-120

Ferron A, Thierry AM, LeDouarin C, Glowinski J (1984): Inhibitory influence of the mesocortical dopaminergic system on spontaneous activity or excitatory response induced from the thalamic mediodorsal nucleus in the rat medial prefrontal cortex. Brain Res 302:257-265

Fleidervish IA, Gutnick MJ (1996): Kinetics of slow inactivation of persistent sodium current in layer V neurons of mouse neocortical slices. J Neurophysiol 76:2125-2130

Fletcher EJ, Church J, MacDonald JF (1994): Haloperidol blocks voltage-gated $\mathrm{Ca}^{2+}$ channels in hippocampal neurons. Eur J Pharmacol 267:249-255

Fletcher P, Frith CD, Grasby PM, Friston KJ, Dolan RJ (1996): Local and distributed effects of apomorphine on frontotemporal function in acute unmedicated schizophrenia. J Neurosci 16:7055-7062

Fletcher P (1998): The missing link: A failure of frontohippocampal integration in schizophrenia. Nature Neurosci 1:266-267

Foehring RC, Surmeier DJ (1993): Voltage-gated potassium currents in acutely dissociated rat cortical neurons. J Neurophysiol 70:51-61

Formenti A, Martina M, Plebani A, Mancia M (1998): Multiple modulatory effects of dopamine on calcium channel kinetics in adult rat sensory neurons. J Physiol 509:395-409

Franz P, Galvan N, Constani A (1986): Calcium-dependent action potentials and associated inward currents in guinea pig neocortical neurons in vitro. Brain Res 366:262-271

Franzen G, Ingvar DH (1975): Absence of activation in frontal structures during psychological testing of chronic schizophrenics. J Neurol Neurosurg Psychiat 38:1027-1032

Fremeau RT Jr, Duncan GE, Fornaretto M-G, Dearry A, Gingrich JA, Breese GR, Caron MG (1991): Localization of D1 dopamine receptor mRNA in brain supports a role in cognitive, affective, and neuroendocrine aspects of dopaminergic neurotransmission. Proc Natl Acad Sci (USA) 88:3772-3776

French CR, Sah P, Buckett KJ, Gage PW (1990): A voltagedependent persistent sodium current in mammalian hippocampal neurons. J Gen Physiol 95:1139-1157 
Friedman A, Gutnick MJ (1989): Intracellular calcium and control of burst generation in neurons of guinea pig neocortex in vitro. Eur J Neurosci 1:374-381

Frith CD (1992): The Cognitive Neuropsychology of Schizophrenia. Hove, UK, Lawrence Erlbaum Associates

Funahashi S, Bruce CJ, Goldman-Rakic PS (1989): Mnemonic coding of visual space in the monkey's dorsolateral prefrontal cortex. J Neurophysiol 61:331-349

Funahashi S, Kubota K (1994): Working memory and prefrontal cortex. Neurosci Res 21:1-11

Fuster JM (1995): Memory in the Cerebral Cortex: An Empirical Approach to Neural Networks in the Human and Nonhuman Primate. Cambridge, MA, The MIT Press

Galarraga E, Hernandez-Lopez S, Reyes A, Barral J, Bargas J (1997): Dopamine facilitates striatal EPSPs through an L-type $\mathrm{Ca}^{2+}$ conductance. Neuroreport 8:2183-2186

Galazzi J-P, Fossett M, Romey G, Laduron P, Lazdunski M (1986): Neuroleptics of the diphenylbutylpiperidine series are potent $\mathrm{Ca}^{2+}$ channel inhibitors. Proc Nat Acad Sci USA 83:7513-7517

Gaspar P, Berger B, Febvret A, Vigny A, Henry J-P (1989): Catecholamine innervation of the human cerebral cortex as revealed by comparative immunohistochemistry of tyrosine hydroxylase and dopamine-beta-hydroxylase. J Comp Neurol 279:249-271

Gaspar P, Bloch B, LeMoine C (1995): D1 and D2 receptor gene expression in the rat frontal cortex: Cellular localization in different classes of efferent neurons. Eur J Neurosci 7:1050-1063

Geijo-Barrientos E, Pastore C (1995): The effects of dopamine on the subthreshold electrophysiological responses of rat prefrontal cortex neurons in vitro. Eur J Neurosci 7:358-366

Ghosh A, Greenberg ME (1995): Calcium signalling in neurons: Molecular mechanisms and cellular consequences. Science 268:239-247

Gillessen T, Alzheimer C (1997): Amplification of EPSPs by low $\mathrm{Ni}^{2+}$ - and amiloride-sensitive $\mathrm{Ca}^{2+}$ channels in apical dendrites of rat CA1 pyramidal neurons. J Neurophysiol 77:1639-1643

Godbout R, Mantz J, Pirot S, Glowinski J, Thierry AM (1991): Inhibitory influence of the mesocortical dopaminergic neurons on their target cells: Electrophysiological and pharmacological characterization. J Pharmacol Exp Therap 258:728-738

Gold JM, Randolph C, Carpenter CJ, Goldberg TE, Weinberger DR (1992): Forms of memory failure in schizophrenia. J Abnorm Psychol 101:487-494

Goldberg TE, Gold JM (1995): Neurocognitive deficits in schizophrenia. In Hirsch SR, Weinberger DR (eds), Schizophrenia. Cambridge, MA, Blackwell, pp 146-162

Goldman-Rakic PS (1991): Prefrontal cortical dysfunction in schizophrenia: The relevance of working memory. In Carroll BJ, Barrett JE (eds), Psychology and the Brain. New York, Raven Press, pp 1-23

Goldman-Rakic PS (1992): Dopamine-mediated mechanisms of the prefrontal cortex. Sem Neurosci 4:149-159

Goldman-Rakic PS (1994): Working memory dysfunction in schizophrenia. J Neuropsychiat Clin Neurosci 6:348-357
Goldman-Rakic PS (1996): Regional and cellular fractionation of working memory. Proc Nat Acad Sci USA 93:13473-13480

Goldman-Rakic PS, Leranth C, Williams SM, Mons N, Geffard M (1989): Dopamine synaptic complex with pyramidal neurons in primate cerebral cortex. Proc Nat Acad Sci USA 86:9015-9019

Goldman-Rakic PS, Lidow MS, Gallager DW (1990): Overlap of dopaminergic, adrenergic, and serotoninergic receptors and complementarity of their subtypes in primate prefrontal cortex. J Neurosci 10:2125-2138

Gorelova N, Yang CR (1997a): The course of neural projection from the prefrontal cortex to the nucleus accumbens in the rat. Neurosci 76:689-706

Gorelova N, Yang CR (1997b): Dopamine D1 receptor stimulation modulates a slowly inactivating $\mathrm{Na}^{+}$current in layer V-VI prefrontal cortical neurons. Soc Neurosci Abst 23: 1771

Gorelova N, Yang CR (1998): Dopamine increases excitability of fast-spiking interneurons in rat medial prefrontal cortex via D1/5 receptor activation. Soc Neurosci Abs 24:350

Gorelova N, Yang CR (submitted): Dopamine D1/5 receptor activation modulates the persistent $\mathrm{Na}^{+}$current in rat layer V-VI prefrontal cortical neurons. J Neurophysiol submitted

Gottesman II (1991): Schizophrenia Genesis: The Origin of Madness. New York, W. H. Freeman and Co.

Gould BJ, Carroll JE, Barrett RJ, Murphy KM, Reynolds IJ (1983): Antipsychotic drugs of the diphenylbutylpiperidine type act as calcium channel antagonists. Proc Nat Acad Sci USA 80:5122-5125

Grace AA (1993): Cortical regulation of subcortical dopamine systems and its possible relevance to schizophrenia. J Neural Transm 91:111-134

Groenewegen HJ, Berendse HW, Wolters JG, Lohman AHM (1990): The anatomical relationship of the prefrontal cortex with the striatopallidal system, the thalamus, and the amygdala: Evidence for a parallel organization. Prog Brain Res 85:95-118

Gulledge AT, Jaffe DB (1996): Dopamine depresses excitatory synaptic transmission onto layer $\mathrm{V}$ pyramidal cells in rat prefrontal cortex. Soc Abst 22:360

Gulledge AT, Jaffe DB (1998): Dopamine decreases the excitatability of layer $\mathrm{V}$ pyramidal cells in the rat prefrontal cortex. J Neurosci 18:9139-9151

Gutfreund Y, Yarom Y, Segev I (1995): Subthreshold oscillations and resonant frequency in guinea pig cortical neurons: Physiology and modeling. J Physiol 483:621-640

Haj-Dahmane S, Andrade R (1997): Calcium-activated cation nonselective current contributes to the fast afterdepolarization in rat prefrontal cortex neurons. J Neurophysiol 78:1983-1989

Hammond C, Crépel F (1992): Evidence for a slowly inactivating $\mathrm{K}^{+}$current in prefrontal cortical cells. Eur J Neurosci 4:1087-1092

Heckers S, Rauch SL, Goff S, Savage CR, Schacter DL, Fischman AJ, Alpert NM (1998): Impaired recruitment of the hippocampus during conscious recollection in schizophrenia. Nature Neurosci 1:318-323 
Hell JW, Westenbroek RE, Warner C, Ahlijanian MK, Prystay W, Gilbert MM, Snutch TP, Catterall WA (1993): Identification and differential subcellular localization of the neuronal class $C$ and class D L-type calcium channel alpha-1 subunits. J Cell Biol 123:949-962

Hernández-López S, Bargas J, Surmeier DJ, Reyes A, Galarraga E (1997): D1 receptor activation enhances evoked discharge in neostriata medium spiny neurons by modulating an L-type $\mathrm{Ca}^{2+}$ conductance. J Neurosci 17:3334-3342

Hillman D, Chen S, Aung TT, Chersksey B, Sugimori M, Llinas RR (1991): Localization of P-type calcium channels in the central nervous system. Proc Nat Acad Sci USA 88:7076-7080

Hirsch JA, Alonso J-M, Reid RC (1995): Visually evoked calcium action potentials in cat striate cortex. Nature 378:612-616

Hirsch JC, Crépel F (1990): Use-dependent changes in synaptic efficiency in rat prefrontal neurons in vitro. J Physiol (London) 427:31-49

Hirsch JC, Crépel F (1991): Blockade of NMDA receptors unmasks a long-term depression in synaptic efficacy in rat prefrontal neurons in vitro. Exp Brain Res 85:621-624

Hirsch JC, Crépel F (1992a): Homo- and heterosynaptic changes in efficacy are expressed in prefrontal neurons: An in vitro study in the rat. Synapse 12:82-85

Hirsch JC, Crépel F (1992b): Postsynaptic calcium is necessary for the induction of LTP and LTD of monosynaptic EPSPs in prefrontal neurons: An in vitro study in the rat. Synapse 10:173-175

Hoffman DA, Magee JC, Colbert CM, Johnston D (1997): $\mathrm{K}^{+}$ channel regulation of signal propagation in dendrites of hippocampal pyramidal neurons. Nature 387:869-875

Huang Q, Zhou D, Chase K, Gusella JF, Aronin N, DiFiglia M (1992): Immunohistochemical localization of the D1 dopamine receptor in rat brain reveals its axonal transport, pre- and postsynaptic localization, and prevalence in the basal ganglia, limbic system, and thalamic reticular nucleus. Proc Nat Acad Sci USA 89:11988-11992

Huguenard JR, Hailll OP, Prince DA (1989): Sodium channels in dendrites of rat cortical pyramidal neurons. Proc Nat Acad Sci USA 86:2473-2477

Ingvar DH, Franzen G (1974): Abnormalities of cerebral blood flow distribution in patients with chronic schizophrenia. Acta Psychiat Scand 50:425-462

Iqbal N, van Praag HM (1995): The role of serotonin in schizophrenia. Eur Neuropsychopharmacol 5:11-23

Ito K, Nakazawa K, Koizumi S, Liu M, Takeuchi K, Hashimoto T, Ohno Y, Inoue K (1996): Inhibition by antipsychotic drugs of L-type $\mathrm{Ca}^{2+}$ channel current in PC12 cells. Eur J Pharmacol 314:143-150

Jablensky A (1995): Schizophrenia: The epidemiological horizon. In Hirsch SR, Weinberger DR (eds), Schizophrenia. Cambridge, MA, Blackwell

Jaffe DB, Johnston D, Lasser-Ross N, Lisman JE, Miyakawa H, Ross WN (1992): The spread of $\mathrm{Na}^{+}$spikes determines the pattern of dendritic $\mathrm{Ca}^{2+}$ entry into hippocampal neurons. Nature 357:244-246

Jarvie KR, Tiber M, Silvia C, Gingrich JA, Caron MG (1993): Molecular cloning, stable expression, and desensitiza- tion of the human dopamine D1B/D5 receptor. J Receptor Res 13:573-590

Jedema HP, Moghaddam B (1994): Glutamatergic control of dopamine release during stress in the rat prefrontal cortex. J Neurochem 63:785-788

Jeffreys JGR, Traub RD, Whittington MA (1996): Neuronal networks for induced " $40 \mathrm{~Hz}$ " rhythms. Trends Neurosci 19:202-208

Johnston D, Magee JC, Colbert CM, Christie B (1996): Active properties of neuronal dendrites. Ann Rev Neurosci 19:165-186

Jones SW, Elmslie KS (1997): Transmitter modulation of neuronal calcium channels. J Memb Biol 155:1-10

Joyce JN (1993): The dopamine hypothesis of schizophrenia: Limbic interactions with serotonin and norepinephrine. Psychopharmacology 112:S16-34

Kansra V, Chen C, Lokhandwala MF (1995): Dopamine causes stimulation of protein kinase $C$ in rat renal proximal tubules by activating dopamine D1 receptors. Eur J Pharmacol 289:391-394

Kanter ED, Kapur A, Haberley LB (1996): A dendritic $\mathrm{GABA}_{\mathrm{A}}$-mediated IPSP regulates facilitation of NMDAmediated responses to burst stimulation of afferent fibers in piriform cortex. J Neurosci 16:307-312

Kapur S, Remington G (1996): Serotonin-dopamine interaction and its relevance to schizophrenia. Am J Psychiat 153:466-476

Karayiorgou M, Gogos JA (1997): A turning point in schizophrenia genetics. Neuron 19:967-979

Karreman M, Moghaddam B (1996): The prefrontal cortex regulates the basal release of dopamine in the striatum: An effect mediated by dopamine cell bodies. J Neurochem 66:589-598

Kavalali ET, Zhou M, Bito H, Tsien RW (1997a): Dendritic $\mathrm{Ca}^{2+}$ channels characterized by recordings from isolated hippocampual dendritic segments. Neuron 18: 651-663

Kavalali ET, Hwang KS, Plummer MR (1997b): cAMPdependent enhancement of dihydropyridine-sensitive calcium channel availability in hippocampal neurons. J Neurosci 17:5334-5348

Kawaguchi Y (1993): Grouping of nonpyramidal and pyramidal cells with specific physiological and morphological characteristics in rat frontal cortex. J Neurophsyiol 69:416-431

Kawaguchi Y (1995): Physiological subgroups of nonpyramidal cells with specific physiological and morphological characteristics in layer II/III of rat frontal cortex. J Neurosci 15:2638-2655

Kawaguchi Y, Kubota Y (1995): Correlation of physiological subgroupings of nonpyramidal cells with parvalbuminand calbindin D28k-immunoreactive neurons in layer $\mathrm{V}$ of rat frontal cortex. J Neurophysiol 70:387-396

Kawaguchi Y, Kubota Y (1996): Physiological and morphological identification of somatostatin- or vasoactive intestinal polypeptide-containing cells among GABAergic cell subtypes in rat frontal cortex. J Neurosci 16:2701-2715

Kim HG, Connors BW (1993): Apical dendrites of the neocortex: Correlation between sodium- and calcium- 
dependent spiking and pyramidal cell morphology. J Neurosci 13:5301-5311

Kim HG, Beierlein M, Connors BW (1995): Inhibitory control of excitable dendrites in neocortex. J Neurophysiol 74:1810-1814

King D, Zigmond MJ, Finlay JM (1997): Effects of dopamine depletion in the medial prefrontal cortex on the stressinduced increase in extracellular dopamine in the nucleus accumbens core and shell. Neuroscience 77: 141-153

Kitai ST, Surmeier DJ (1993): Cholinergic and dopaminergic modulation of potassium conductances in neostriatal neurons. Adv Neurol 60:40-52

Klink R, Alonso A (1993): Ionic mechanisms for the subthreshold oscillations and differential electroresponsiveness of medila entorhinal cortex layer II neurons. J Neurophysiol 70:144-157

Kolb, B (1984): Functions of the frontal cortex of the rat: A comparative review. Brain Res Rev 8:65-98

Komondi A, Acsády L, Buzsáki G (1998): Dendritic spikes are enhanced by cooperative network activity in the intact hippocampus. J Neurosci 18:3919-3928

König P, Engel A (1995): Correlated firing in sensory-motor systems. Curr Opin Neurobiol 5:511-519

König P, Engel AK, Singer W (1996): Integrator or coincidental detector? The role of the cortical neuron revisited. Trends Neurosci 19:130-137

Krimer LS, Jakab RL, Goldman-Rakic PS (1997): Quantitative three-dimensional analysis of the catecholaminergic innervation of identified neurons in the macaque prefrontal cortex. J Neurosci 17:7450-7461

Kritzer MF, Goldman-Rakic PS (1995): Intrinsic circuit organization of the major layers and sublayers of the dorsolateral prefrontal cortex in the rhesus monkey. J Comp Neurol 359:131-143

Lampl I, Yarom Y (1993): Subthreshold oscillations of the membrane potential: A functional synchronizing and timing device. J Neurophysiol 70:2181-2186

Laurier LG, O'Dowd BF, George SR (1994): Heterogeneous tissue-specific transciption of dopamine receptor subtype messenger RNA in rat brain. Mole Brain Res 25:344-350

Law-Tho D, Hirsch JC, Crépel F (1994): Dopamine modulation of synaptic transmission in rat prefrontal cortex: An in vitro electrophysiological study. Neurosci Res 21: 151-160

Levitt JB, Lewis DA, Yoshioka T, Lund J (1993): Topography of pyramidal neuron intrinsic connections in macaque monkey prefrontal cortex (area 9 and 46). J Comp Neurol 338:360-376

Lewis DA, Hayes TL, Lund JS, Oeth K (1992): Dopamine and the neural circuitry of primate prefrontal cortex: Implications for schizophrenia research. Neuropsychopharmacology 6:127-134

Lewis DA, Anderson SA (1995): The functional architecture of the prefrontal cortex and schizophrenia. Psychol Med 25:887-894

Lewis DA (1997): Development of the prefrontal cortex during adolescence: Insights into vulnerable neural circuits in schizophrenia. Neuropsychopharmacology 16:385398
Liddle PF (1996): Functional imaging-schizophrenia. Brit Med Bull 52:486-494

Liddle PF, Friston KJ, Frith CD, Jones T, Hirsch SR, Frackowiak RSJ (1992): Patterns of cerebral blood flow in schizophrenia. Brit J Psychiat 160:179-186

Lidefors N, Brene S, Herrera-Marschitz M, Persson H (1989): Region-specifc regulation of glutamic acid decarboxylase mRNA expression by dopamine neurons in the rat brain. Exp Brain Res 77:611-620

Lidow MS, Goldman-Rakic PS, Gallager DW, Rakic P (1991): Distribution of dopaminergic receptors in the primate cerebral cortex: Quantitative autoradiographic analysis using $\left[{ }^{3} \mathrm{H}\right]$ raclopride, $\left[{ }^{3} \mathrm{H}\right]$ spiperone and $\left[{ }^{3} \mathrm{H}\right] \mathrm{SCH} 23390$. Neuroscience 40:657-671

Lidow MS, Wang F, Cao Y, Goldman-Rakic PS (1998): Layer $\mathrm{V}$ neurons bear the majority of mRNAs encoding the five distinct dopamine receptor subtypes in the primate prefrontal cortex. Synapse 28:10-20

Lipowsky R, Gillessen T, Alzeheimer C (1996): Dendritic $\mathrm{Na}^{+}$channels amplify EPSPs in hippocampal CA1 pyramidal cells. J Neurophysiol 76:2181-2191

Lisman J (1994): The CaM kinase II hypothesis for the storage of synaptic memory. Trends Neurosci 17:406-412

Llinas R, Grace AA, Yarom Y (1991): In vitro neurons in mammalian cortical layer 4 exhibit intrinsic oscillatory activity in the $10-$ to $50-\mathrm{Hz}$ frequency range. Proc Nat Acad Sci USA 88:897-901

MacVicar BA (1984): Infrared video microscopy to visualize neurons in the in vitro brain slice preparation. J Neurosci Meth 12:133-139

Magee JC, Hoffman D, Colbert C, Johnston D (1998): Electrical and calcium signaling in dendrites of hippocampal pyramidal neurons. Ann Rev Physiol 60:327-346

Magee JC, Johnston D (1995a): Synaptic activation of voltage-gated channels in the dendrites of hippocampal pyramidal neurons. Science 268:301-304

Magee JC, Johnston D (1995b): Characterization of single voltage-gated $\mathrm{Na}^{+}$and $\mathrm{Ca}^{2+}$ channels in apical dendrites of rat CA1 pyramidal neurons. J Physiol (London) 487:67-90

Magee JC, Avery RB, Christie BR, Johnston D (1996): Dihydropyridine-sensitive, voltage-gated $\mathrm{Ca}^{2+}$ channels contribute to the resting intracellular $\mathrm{Ca}^{2+}$ concentration of hippocampal CA1 pyramidal neurons. J Neurophysiol 76:3460-3470

Magee JC, Johnston D (1997): A synaptically controlled, associated signal for Hebbian plasticity in hippocampal neurons. Science 275:209-213

Mansour A, Meader-Woodruff JH, Bunzow JR, Civelli O, Akil H, Watson SJ (1990): Localization of dopamine D2 receptor mRNA and D1 and D2 receptor binding in the rat brain and pituitary: An in situ hybridization-receptor autoradiographic analysis. J Neurosci 10:2587-2600

Mansour A, Meader-Woodruff JH, Zhou Q-Y, Civelli O, Akil H, Watson SJ (1991): A comparison of D1 receptor binding and mRNA in rat brain using receptor autographic and in situ hybridization techniques. Neuroscience 45:359-371

Marchetti C, Carbone E, Lux HD (1986): Effects of dopamine and noradrenaline on $\mathrm{Ca}^{2+}$ channels of cultured sensory 
and sympathetic neurons of chick. Pflügers Archiv Europ J Physiol 406:104-111

Marek GJ, Aghajanian GK (1998): The electrophysiology of prefrontal serotonin systems: Therapeutic implications for mood and psychosis. Biol Psychiat 44:1118-1127

Markram H (1997): A network of tufted layer 5 pyramidal neurons. Cereb Cortex 7:523-533

Markram H, Sakmann B (1994): Calcium transients in dendrites of neocortical neurons evoked by single subthreshold excitatory postsynaptic potentials via lowvoltage-activated calcium channels. Proc Nat Acad Sci USA 91:5207-5211

Markram H, Helm PJ, Sakmann B (1995): Dendritic calcium transients evoked by single back-propagating action potentials in rat neocortical pyramidal neurons. J Physiol (London) 485:1-20

Markram H, Lübke J, Frostscher M, Sakmann B (1997a): Regulation of synaptic efficacy by coincidence of postsynaptic APs and EPSPs. Science 275:213-217

Markram H, Lübke J, Frostscher M, Roth A, Sakmann B (1997b): Physiology and anatomy of synaptic connections between thick tufted pyramidal neurons in the developing rat neocortex. J Physiol (London) 500:409440

Masukawa LM, Prince DA (1984): Synaptic control of excitability in isolated dendrites of hippocampal neurons. J Neurosci 4:217-227

Mathew RJ, Wilson WH, Tant SR, Robinson L, Prakash R (1988): Abnormal resting regional cerebral blood flow patterns and their correlates in schizophrenia. Arch Gen Psychiatry 45:542-549.

Matsumoto M, Hidaka K, Tada S, Tasaki T, Yamaguchi T (1996): Low levels of mRNA for dopamine D4 receptor in human cerebral cortex and striatum. J Neurochem 66:915-919

Mattay VS, Berman KF, Ostrem JL, Esposito G, van Horn JD, Bigelow LB, Weinberger DR (1996): Dextroamphetamine enhances "neural network-specific" physiological signals: Positron emission tomography rCBF study. J Neurosci 16:4816-4822

McCabe RT, Wasterlain CG, Kucharczk N, Sofia RD, Vogel JR (1993): Evidence for anticonvulsant and neuroprotectant action of felbamate mediated by strychnineinsensitive glycine receptors. J Pharmacol Exp Therp 264:1248-1252

McMillian MK, He XP, Hong JS, Pennypacker KR (1992): Dopamine stimulates [ $\left.{ }^{3} \mathrm{H}\right]$ phorbol 12,13-dibytyrate binding in cultured stiratal cells. J Neurochem 58:13081312

Mel BW (1994): Information processing in dendritic trees. Neural Comput 6:1031-1085

Meador-Woodruff JH, Mansour A, Bunzow J, Van Tol HHM, Watson SJ, Civelli O (1989): Distribution of D2 dopamine receptor mRNA in rat brain. Proc Nat Acad Sci USA 86:7625-7628

Meador-Woodruff JH, Damask SP, Wang J-C, Haroutunian V, Davis KL, Watson SJ (1996): Dopamine receptor mRNA expression in human striatum and neocortex. Neuropsychopharmacology 15:17-29
Mengod G, Vilaró MT, Niznik HB, Sunahara RK, Seeman P, O'Dowd BF, Palacios JM (1991): Visualization of a dopamine D1 receptor mRNA in human and rat brain. Mol Brain Res 10:185-191

Midgaard J (1994): Processing of information from different sources: Spatial synaptic integration in the dendrites of vertebrate CNS neurons. Trends Neurosci 17:166-173

Miles R, Toth K, Gulyás-Hájos N, Freund TF (1996): Difference between somatic and dendritic inhibition in the hippocampus. Neuron 16:815-823

Miller JP, Rall W, Rinzel J (1985): Synaptic amplification by active membrane in dendritic spines. Brain Res 325:325330

Mills LR, Niesen CE, So AP, Carlen PL, Spigelman I, Jones OT (1994): N-type $\mathrm{Ca}^{2+}$ channels are located on somata, dendrites, and a subpopulation of dendritic spines on live hippocampal pyramidal neurons. J Neurosci 14: $6815-6824$

Mitchell BD, Cauller LJ (1997): Corticocortical and thalamocortical projections to layer I of the prefrontal/premotor neocortex in rats. Soc Neurosci Abst 23:1273

Mitchell JB, Gratton A (1992): Partial dopamine depletion of the prefrontal cortex leads to enhanced mesolimbic dopamine release elicited by repeated exposure to naturally reinforcing stimuli. J Neurosci 12:3609-3618

Miura M, Yoshioka M, Miyakawa H, Kato H, Ken-Ichi I (1997): Properties of calcium spikes revealed during $\mathrm{GABA}_{\mathrm{A}}$ receptor antagonism in hippocampal CA1 neurons from guinea pigs. J Neurophysiol 78:2269-2279

Moghaddam B, Adams BW (1998): Reversal of phencyclidine effects by a group II metabotropic glutamate receptor agonist in rats. Science 281:1349-1352

Mogenson GJ, Brudzynski S, Wu M, Yang CR, Yim CY (1993): From motivation to action: A review of dopaminergic regulation of limbic $\rightarrow$ nucleus accumbens $\rightarrow$ ventral pallidum $\rightarrow$ pedunculopontine nucleus circuitries involved in limbic-motor integration. In Kalivas P, Barnes C (eds), The Mesolimbic Motor Circuit and Its Role In Neuropsychiatric Disorders. Boca Raton, FL, CRC Press, pp 193-236

Moorman JR, Kirsch GE, Van Dongen AM, Joho RH, Brown AM (1990): Fast and slow gating of sodium channels encoded by a single mRNA. Neuron 4:243-252

Mrzijak L, Bergson C, Pappy M, Huff R, Levenson R, Goldman-Rakic PS (1996): Localization of dopamine D4 receptors in GABAergic neurons of the primate brain. Nature 381:245-248

Muly EC, Szigeti K, Goldman-Rakic PS (1997): D1 dopamine receptors are present in parvalbumin-positive interneurons in macaque prefrontal cortex. Soc Neurosci Abs 23:1772

Murase S, Grenhoff J, Chouvet G, Gonon FG, Svensson TH (1993): Prefrontal cortex regulates burst firing and transmitter release in rat mesolimbic dopamine neurons studied in vivo. Neurosci Lett 157:53-56

Murphy BL, Arnsten AFT, Goldman-Rakic PS, Roth RH (1996): Increased dopamine turnover in the prefrontal cortex impairs spatial working memory performance in rats and monkeys. Proc Nat Acad Sci USA 93:1325-1329

Ng GYK, Mouillac B, George S, Caron M, Dennis M, Bouvier 
M, O'Dowd BF (1994): Desensitization, phosphorylation, and palmitoylation of the human dopamine D1 receptor. Eur J Pharmacol 267:7-19

Ng GYK, Trogadis J, Stevens J, Bouvier M, O’Dowd BF, George SR (1995): Agonist-induced desensitization of dopamine D1 recptor-stimulated adenylyl cyclase activity is temporally and biochemically separated from D1 receptor internalization. Proc Nat Acad Sci USA 92: 10157-10161

Nisenbaum ES, Zao CX, Wilson CJ (1994): Contribution of a slowly inactivating potassium current to the transition to firing of neostriatal spiny projection neurons. J Neurophysiol 71:1174-1189

Nisenbaum ES, Wilson CJ, Foehring RC, Surmeier J (1996): Isolation and characterization of a persistent potassium current in neostiratal neurons. J Neurophysiol 76:11801194

Nisenbaum ES, Mermelstein PG, Wilson CJ, Surmeier DJ (1998): Selective blockade of a slowly inactivating potassium current in striatal neurons by $( \pm)$ 6-chloro-APBhydrobromide (SKF82958). Synapse 29:213-224

Niznik HB, van Tol HHM (1992): Dopamine receptor genes: New tools for molecular psychiatry. J Psychiat Neurosci 17:158-180

Numan R, Catterall WA, Scheuer T (1991): Functional modulation of brain sodium channels by protein kinase $\mathrm{C}$ phosphorylation. Science 254:115-118

Ogata N, Yoshi M, Narahashi T (1989): Psychotropic drugs block voltage-gated ion channels in neuroblastoma cells. Brain Res 476:140-147

Ogawa N (1995): Molecular and chemical neuropharmacology of dopamine receptor subtypes. Acta Med Okayma 49:1-11

Okubo Y, Suhara T, Suzuki K, Kabayashi K, Inoue O, Tarasaki O, Somiya Y, Sassa T, Sudo Y, Matsushima E, Iyo M, Tatono Y, Toru M (1997): Decreased prefrontal dopamine D1 receptors in schizophrenia revealed by PET. Nature 385:634-636

Olney JW, Farber NB (1995): Glutamate receptor dysfunction and schizophrenia. Arch Gen Psychiat 52:998-1007

Otani S, Blond O, Desce J-M, Crépel F (1998): Dopamine facilitates long-term depression of glutamatergic transmission in rat prefrontal cortex. Neuroscience 85:669-676

Park S, Holzman PS (1992): Schizophrenics show spatial working memory deficits. Arch Gen Psychiat 49:975982

Park S, Holzman PS (1993): Association of working memory deficits and eye-tracking dysfunction in schizophrenia. Schizo Res 11:55-61

Paupardin-Tritsch D, Colombaioni L, Deterre P, Gerschenfeld HM (1985): Two different mechanisms of calcium spike modulation by dopamine. J Neurosci 5:2522-2532

Penit-Soria J, Audinat E, Crépel F (1987): Excitation of rat prefrontal cortical neurons by dopamine: An in vitro electrophysiological study. Brain Res 425:263-274

Perkel DJ, Petrozzino JJ, Nicoll RA, Connor JA (1993): The role of $\mathrm{Ca}^{2+}$ entry via synaptically activated NMDA receptors in the induction of long-term potentiation. Neuron 11:817-823
Peters A (1987): Number of neurons and synapses in primary visual cortex. In Jones EG, Peters A (eds), Cerebral Cortex: Further Aspects of Cortical Function, Including Hippocampus. New York, Plenum Press, pp 267-294

Pfeiffer-Linn CL, Lasater EM (1996): Dopamine modulates unitary conductance of single PL-type calcium channels in Roccus Chrysops retinal horizontal cells. J Physiol (London) 496:607-616

Pfefferbaum A, Marsh L (1995): Structural brain imaging in schizophrenia. Clin Neurosci 3:105-111

Phillipson OT (1979): Afferent projections to the ventral tegmental area of Tsai and interfascicular nucleus: A horseradish peroxidase study in the rat. J Comp Neurol 187:117-144

Pirot S, Godbout R, Mantz J, Tassin JP, Glowinski J, Thierry AM (1992): Inhibitory effects of ventral tegmental area stimulation on the activity of prefrontal cortical neurons: Evidence for involvement of both dopaminergic and GABAergic components. Neuroscience 49:857-865

Pirot S, Jay TM, Glowinski J, Thierry AM (1994): Anatomical and electrophysiological evidence for an excitatory amino acid pathway from the thalamic mediodorsal nucleus to the prefrontal cortex in the rat. Eur J Neurosci 6:1225-1234

Pirot S, Jay TM, Glowinski J, Thierry AM (1996): Mediodorsal thalamic evoked responses in the rat prefrontal cortex: Influence of the mesocortical DA system. Neuroreport 7:1437-1441

Porrino LJ, Goldman-Rakic PS (1982): Brain stem innervation of prefrontal and anterior cingulate cortex in the rhesus monkey revealed by retrograde transport of HRP. J Comp Neurol 205:63-76

Posner MI, Early TS, Reiman E, Pardo PJ, Dhawan M (1988): Asymmetries in hemispheric control attention in schizophrenia. Arch Gen Psychiat 45:814-821

Pucak ML, Levitt JB, Lund JS, Lewis DA (1996): Patterns of intrinsic and associational circuitry in monkey prefrontal cortex. J Comp Neurol 376:614-630

Quirion R, Lafaille F, Nair NPV (1985): Comparative potencies of $\mathrm{Ca}^{2+}$ channels antagonists and antischizophrenic drugs on central and peripheral $\mathrm{Ca}^{2+}$ channel binding sites. J Pharm Pharmacol 37:437-452

Rall W, Burke RE, Holmes WR, Jack JJB, Redman SJ, Segev I (1992): Matching dendritic neuron models to experimental data. Physiol Rev 72:S159-S186

Reader TA, Ferron A, Descarries L, Jasper HH (1979): Modulatory role for biogenic amines in the cerebral cortex. Microiontophoretic studies. Brain Res 160:217-229

Rho JM, Donevan SD, Rogawski MA (1994): Mechanism of action of the anticonvulsant felbamate: Opposing effects on N-methyl-D-aspartate and $\gamma$-aminobutyric acid $_{\mathrm{A}}$ receptors. Ann Neurol 35:229-234

Regehr WG, Tank DW (1990): Postsynaptic NMDA receptormediated calcium accumulation in hippocampal CA1 pyramidal cell dendrites. Nature 345:807-810

Regehr WG, Tank DW (1992): Calcium concentration dynamics produced by synaptic activation of CA1 hippocampal pyramidal cells. J Neurosci 12:4202-4223

Regehr W, Kehoe J, Ascher P, Armstrong C (1993): Synapti- 
cally triggered action potentials in dendrites. Neuron 11:145-151

Rétaux S, Besson MJ, Penit-Soria J (1991): Opposing effects of dopamine D2 receptor stimulation on the spontaneous and the electrically evoked release $\left[{ }^{3} \mathrm{H}\right.$ GABA] on rat prefrontal cortex slices. Neuroscience 42:61-71

Rétaux S, Trovero F, Besson MJ (1994): Role of dopamine in the plasticity of gluatmic acid decarboxylase messenger RNA in the rat frontal cortex and the nucleus accumbens. Eur J Neurosci 6:1782-1791

Reuveni I, Friedman A, Amitai Y, Gutnick MJ (1993): Stepwise repolarization from $\mathrm{Ca}^{2+}$ plateaus in neocortical pyramidal cells: Evidence for nonhomogeneous distribution of $\mathrm{HVA} \mathrm{Ca}^{2+}$ channels in dendrites. J Neurosci 13:4609-4621

Roberts GW, Bruton CJ (1990): Notes from the graveyard: Neuropathology and schizophrenia. Neuropathol App Neurobiol 16:3-16

Ross CA, Pearlson GD (1996): Schizophrenia, the heteromodal association neocortex and development: Potential for a neurogenetic approach. Trends Neurosci 19:171-176

Sah P, Nicoll RA (1991): Mechanisms underlying potentiation of synaptic transmission in rat anterior cingulate cortex in vitro. J Physiol (London) 433:615-630

Sah DWY, Bean BP (1994): Inhibition of P-type and N-type calcium channels by dopamine receptor antagonists. Mol Pharmacol 45:84-92

Sakai M, Hamada I (1981): Intracellular activity and morphology of the prefrontal neurons related to visual attention task in behaving monkeys. Exp Brain Res 41:195-198

Sawaguchi T (1987): Catecholamine sensitivities neuron related to a visual reaction time task in the monkey prefrontal cortex. J Neurophysiol 48:1100-1122

Sawaguchi T, Matsumura M, Kubota K (1990a): Catecholamine effects on neuronal activity related to a delayed response task in monkey prefrontal cortex. J Neurophysiol 63:1385-1400

Sawaguchi T, Matsumura M, Kubota K (1990b): Effects of dopamine antagonists on neuronal activity related to a delayed response task in monkey prefrontal cortex. J Neurophysiol 63:1401-1412

Sawaguchi T, Goldman-Rakic PS (1994): The role of D1dopamine receptor in working memory: Local injections of dopamine antagonists into the prefrontal cortex of rhesus monkeys performing an oculomotor delayedresponse task. J Neurophysiol 71:515-528

Sayer RJ, Schwindt PC, Crill WE (1990): High- and lowthreshold calcium currents in neurons acutely isolated from rat sensorimotor cortex. Neurosci Lett 120:175-178

Sayer RJ, Brown AM, Schwindt PC, Crill WE (1993): Calcium currents in acutely isolated human neocortical neurons. J Neurophysiol 69:1596-1606

Saykin AJ, Gur RC, Gur RE, Mozley D, Mozley LH, Resnick SM, Kester B, Stafiniak P (1991): Neuropsychological function in schizophrenia: Selective impairment in memory and learning. Arch Gen Psychiat 48:618-624

Schiffmann SN, Lledo PM, Vincent JD (1995): Dopamine D1 receptor modulates the voltage-gated sodium current in rat striatal neurons through a protein kinase A. J Physiol (London) 483:95-107

Schiller J, Helmchen F, Sakmann B (1995): Spatial profile of dendritic calcium transients evoked by action potentials in rat neocortical pyramidal neurons. J Physiol (London) 489:583-600

Schiller J, Schiller Y, Stuart G, Sakmann B (1997): Calcium action potential restricted to distal apical dendrites of rat neocortical pyramidal neurons. J Physiol (London) 505:605-616

Schwindt PC (1992): Ionic currents governing input-output relations of Betz cells. In McKenna T, Davis J, Zornnetzer SF (eds), Single Neuron Computation. New York, Academic Press, Chapter 9, pp 235-258

Schwindt PC, Crill W (1995): Amplification of synaptic current by persistent sodium conductance in apical dendrite of neocortical neurons. J Neurophysiol 74:22202224

Schwindt PC, Crill W (1997a): Local and propagated dendritic action potentials evoked by glutamate iontophoresis on rat neocortical pyramidal neurons. J Neurophysiol 77:2466-2483

Schwindt PC, Crill W (1997b): Modification of current transmitted from apical dendrite to soma by blockade of voltage- and $\mathrm{Ca}^{2+}$-dependent conductances in rat neocortical pyramidal neurons. J Neurophysiol 78:187-198

Schwindt PC, Crill W (1998): Synaptically evoked dendritic action potentials in rat neocortical pyramidal neurons. J Neurophysiol 79:2432-2446

Schwindt PC, Spain WJ, Foering RkC, Stafstrom CE, Chubb MC, Crill WE (1988): Multiple potassium conductances and their functions in neurons from cat sensorimotor cortex. J Neurophysiol 59:424-449

Seamans JK, Gorelova N, Yang CR (1997): Contribution of voltage-gated $\mathrm{Ca}^{2+}$ potentials in the proximal versus distal dendrites to synaptic integration in prefrontal cortical neurons. J Neurosci 17:5936-5948

Seamans JK, Floresco SB, Phillips AG (1998): D1 Receptor modulation of hippocampal-prefrontal cortical circuits integrating spatial memory with executive functions in the rat. J Neurosci 18:1613-1621

Seeman P (1992): Dopamine receptor sequences: Therapeutic levels of neuroleptics occupy D2 receptors, clozapine occupies D4. Neuropsychopharmacology 7:261-284

Séguéla P, Watkins KC, Descarries L (1988): Ultrastructural features of dopamine axon terminals in the anteromedial and the suprarhinal cortex of adult rat. Brain Res 442:11-22

Selemon LD, Rajkowska G, Goldman-Rakic PS (1995): Abnormally high neuronal density in the schzophrenic cortex. Arch Gen Psychiat 52:805-818

Selemon LD, Rajkowska G, Goldman-Rakic PS (1998): Elevated neuronal density in prefrontal area 46 in brains from schizophrenic patients: apAlication of a threedimensional stereologic counting method. J Comp Neurol 392:402-412

Sesack SR, Bunney BS (1989): Pharmacological characterization of the receptor mediating electrophysiological responses to dopamine in rat medial prefrontal cortex: 
A microiontophoretic study. J Pharmacol Exp Therap 248:1323-1333

Sesack SR, Deutch AY, Roth RH, Bunney BS (1989): Topographical organization of the efferent projections of the medial prefrontal cortex in the rat: An anterograde tract-tracing study with phaseolus vulgaris leucoagglutinin. J Comp Neurol 290:213-242

Sesack SR, Pickel VM (1992): Prefrontal cortical efferents in the rat synapse on unlabeled neuronal targets of catecholamine terminals in the nucleus accumbens septi and on dopamine neurons in the ventral tegmental area. J Comp Neurol 320:145-160

Sesack SR, Snyder CL, Lewis D (1995): Axon terminals immunolabeled for dopamine or tyrosine hydroxylase synapse on GABA-immunoreactive dendrites in rat and monkey cortex. J Comp Neurol 363:264-280

Shapiro RM (1993): Regional neuropathology in schizophrenia: Where are we? Where are we going? Schizophrenia Res 10:187-239

Shepherd GM, Brayton RK, Miller JP, Segev I, Rinzel J, Rall W (1985): Signal enhancement in distal cortical dendrites by means of interactions between active dendritic spines. Proc Nat Acad Sci USA 82:2192-2195

Shi W-X, Zheng P, Liang X-F, Bunney BS (1997): Characterization of dopamine-induced depolarization of prefrontal cortical neurons. Synapse 26:415-422

Simon H, Scatton B, Le Moal M (1980): Dopaminergic A10 neurones are involved in cognitive functions. Nature 286:150-151

Singer W (1993): Synchronization of cortical activity and its putative role in information processing and learning. Ann Rev Physiol 55:274-349

Singer W, Gray CM (1995): Visual feature integration and the temporal correlation hypothesis. Ann Rev Neurosci 18:555-586

Smiley JF, Williams M, Szigeti K, Goldman-Rakic PS (1992): Light and electron microscopic characterization of dopamine-immunoreactive axons in human cerebral cortex. J Comp Neurol 321:325-335

Smiley JF, Goldman-Rakic PS (1993): Heterogeneous targets of dopamine synapses in monkey prefrontal cortex demonstrated by serial section electron microscopy: A laminar analysis using the silver-enhanced diaminobenzidone sulfide (SEDS) immunolabeling technique. Cereb Cortex 3:223-238

Smith RD, Goldin AL (1997): Phosphorylation at a single site in the rat brain sodium channel is necessary and sufficient for current reduction by protein kinase A. J Neurosci 17:6086-6093

Sokoloff P, Giros B, Martes M-P, Bouthenet M-L, Schwartz J-C (1990): Molecular cloning and characterization of a novel dopamine receptor (D3) as a target for neuroleptics. Nature 347:146-151

Soltesz I, Smetter DK, Mody I (1995): Tonic inhibition originates from synapses close to the soma. Neuron 14:12731283

Spruston N, Schiller Y, Stuart G, Sakmann B (1995): Acitivity-dependent action potential invasion and calcium influx into hippocampal CA1 dendrites. Science 268: 297-300
Stafstrom CE, Schwindt PC, Chubb MC, Crill WE (1985): Properties of persistent sodium conductance and calcium conductance of layer $\mathrm{V}$ neurons from cat sensorimotor cortex in vitro. J Neurophysiol 53:153-170

Stevens JR (1992): Abnormal reinnervation as a basis for schizophrenia. Arch Gen Psychiat 49:238-243

Storm JF (1988): Temporal integration by a slowly inactivating $\mathrm{K}^{+}$current in hippocampal neurons. Nature 336: 379-381

Stuart GJ, Sakmann B (1994): Active propagation of somatic action potentials into neocortical pyramidal cell dendrites. Nature 367:69-72

Stuart GJ, Sakmann B (1995): Amplification of EPSPs by axosomatic sodium channels in neocortical pyramidal neurons. Neuron 15:1065-1076

Stuart GJ, Spruston N (1995): Probing dendritic function with patch pipettes. Current Opin Neurobiol 5:389-394

Stuart GJ, Spruston N (1998): Determinants of voltage attenuation in neocortical pyramidal neuron dendrites. J Neurosci 18:3501-3510

Stuart GJ, Dodt HU, Sakmann B (1993): Patch-clamp recordings from the soma and dendrites of neurons in brain slices using infrared video mciroscopy. Pfluger Arch Eur J Physiol 423:511-518

Stuart G, Schiller J, Sakmann B (1997): Action potential initiation and propagation in rat neocortical pyramidal neurons. J Physiol 505:617-32

Sunahara RK, Guan H-C, O'Dowd BF, Seeman P, Laurier LG, Ng G, George SR, Torchia J, Van Tol HHM, Niznik HB (1991): Cloning of the gene for a human dopamine D5 receptor with higher affinity for dopamine than D1. Nature 350:614-619

Surmeier DJ, Eberwine J, Wilson CJ, Cao Y, Stefani A, Kitai ST (1992): Dopamine receptor subtypes colocalize in rat striatonigral neurons. Proc Nat Acad Sci USA 89:1017810182

Surmeier DJ, Bargas J, Hemming HC Jr, Nairn AC, Greengard P (1995): Modulation of calcium currents by a D1 dopaminergic protein kinase/phosphatase cascade in rat neostriatal neurons. Neuron 14:385-397

Sutor B, Zieglgansberger W (1987): A low-voltage activated, transient calcium current is responsible for the timedependent depolarizing inward rectification of rat neocortical neurons in vitro. Pflueger Arch Eur J Physiol 410:102-111

Suzuki H, Azuma M (1977): Prefrontal neuronal activity during gazing at a light spot in the monkey. Brain Res 126:497-508

Svoboda K, Denk W, Kleinfeld D, Tank DW (1997): In vivo dendritic calcium dynamics in neocortical pyramidal neurons. Nature 385:161-165

Swanson LW (1982): The projections of the ventral tegmental area and adjacent regions: A combined fluorescent retrograde tracer and immunofluorescence study in the rat. Brain Res Bull 9:321-353

Swanson LW, Kohler C (1986): Anatomical evidence for direct projections from the entorhinal area to the entire cortical mantle in the rat. J Neurosci:3010-3023 
Taber M, Das S, Fibiger HC (1995): Cortical regulation of subcortical dopamine release: Mediation via ventral tegmental area. J Neurochem 6:61407-61410

Thompson AM, Deuchars J (1997): Synaptic interactions in neocortical local circuits: Dual intracellular recordings in vitro. Cereb Cortex 7:510-522

Tsubokawa H, Ross WN (1996): IPSPs modulate spike backpropagation and associated $\left[\mathrm{Ca}^{2+}\right]_{\mathrm{i}}$ changes in the dendrites of hippocampal CA1 pyramidal neurons. J Neurophysiol 76:2896-2906

Uylings HBM, van Eden CG (1990): Qualitative and quantitive comparison of the prefrontal cortex in rat and in primates, including humans. Prog Brain Res 85:31-61

Vaadia E, Haalman I, Abeles M, Bergman H, Prut Y, Slovin $H$, Aertsen A (1995): Dynamics of neuronal interactions in monkey cortex in relation to behavioral events. Nature 373:515-518

van Eden CG, Hoorneman EMD, Buijs RM, Mathussen MAH, Geffard M, Uylings HBM (1987): Immunohistochemical localization of dopamine in the prefrontal cortex of the rat at the light, electron microscopical level. Neurosci 22:849-862

van Eden CG, Lamme VAF, Uylings HBM (1992): Heterotopic cortical afferents to the medial prefrontal cortex in the rat. Combined retrograde and anterograde tracer study. Eur J Neurosci 4:77-97

van Tol HHM, Bunzow JR, Guan HC, Sunahara RK, Seeman P, Niznik HB, Civelli O (1991): Cloning of the gene for a human dopamine D4 receptor with high affinity for the antipsychotic clozapine. Nature 350:610-614.

Verney C, Alvarez C, Geffard M, Berger B (1990): Ultrastructural double labeling study of dopamine terminals and GABA-containing neurons in rat anteromedial cerebral cortex. Eur J Neurosci 2:295-298

Vincent SL, Khan Y, Benes FM (1993): Cellular distribution of dopamine D1 and D2 receptors in rat medial prefrontal cortex. J Neurosci 13:2551-2564

Vincent SL, Khan Y, Benes FM (1995): Cellular colocalization of dopamine D1 and D2 receptors in rat medial prefrontal cortex. Synapse 19:112-120

Watanabe M, Kodama T, Hikosaka K (1997): Increase of extracellular dopamine in primate prefrontal cortex during a working memory task. J Neurophysiol 78: 2795-2798

Weinberger DR (1991): Anteromedial temporal-prefrontal connectivity: A functional neuroanatomical system implicated in schizophrenia. In Carroll BJ, Barrett JE (eds), Psychpathology and the Brain. New York, Raven, pp 25-43

Weinberger DR (1996): On the plausibility of "the neurodevelopmental hypothesis" of schizophrenia. Neuropsychopharmacology 14:S1-S11

Weinberger DR, Berman KF (1996): Prefrontal function in schizophrenia: Confounds and controversies. Phil Trans Roy Soc London Series B 351:1495-1503

Weinberger DR, Berman KF, Zee RF (1986): Physiological dysfunction of dorsolateral prefrontal cortex in schizophrenia I. Regional cerebral blood flow evidence. Arch Gen Psychiat 43:114-124
Westenbroek RE, Merrick DK, Catterall WA (1989): Differential subcellular localization of the R1 and RII $\mathrm{Na}^{+}$ channel subtypes in central neurons. Neuron 3:694-704

Westenbroek RE, Ahlijhanian MK, Catterall WA (1990): Clustering of L-type $\mathrm{Ca}^{2+}$ channels at the base of major dendrites in hippocampal pyramidal neurons. Nature 347:281-284

Westenbroek RE, Hell JW, Warner C, Dubel SJ, Snutch TP, Catterall WA (1992): Biochemical properties and subcellular distribution of an N-type calcium channel alpha 1 subunit. Neuron 9:1099-1115

Whittington MA, Traub RD, Jeffreys JGR (1995): Synchronized oscillations in interneuronal networks driven by metabotropic glutamate receptor activation. Nature 373:612-615

Williams GV, Goldman-Rakic PS (1995): Modulation of memory fields by dopamine D1 receptors in prefrontal cortex. Nature 376:572-575

Williams PJ, MacVicar BA, Pittman QJ (1990): Synaptic modulation by dopamine of calcium currents in rat pars intermedia. J Neurosci 10:757-763

Williams SM, Goldman-Rakic PS (1993): Characterization of the dopaminergic innervation of the primate frontal cortex using a dopamine-specific antibody. Cereb Cortex 3:199-222

Wilson FAW, Scalaidhe SPO, Goldman-Rakic PS (1994): Functional synergism between putative $\gamma$-aminobutyrate-containing neurons and pyramidal neurons in prefrontal cortex. Proc Nat Acad Sci USA 91:4009-4013

Wolkin A, Sanfilipo M, Wolf AP, Angrist B, Brodie JD, Rostrosen J (1992): Negative symptoms and hypofrontality in chronic schizophrenia. Arch Gen Psychiat 49:959-965

Wong DF, Giedde A, Reith J, Grunder G, Szymanski S, Yokoi F, Hong C, Nestadt G, Neufeld K, Pearlson G, Tune L, Angrist B (1997): Imaging intrasynaptic, postsynaptic, and presynaptic dopamine dysfunction in psychosis. Soc Neurosci Abs 23:1405

Yang CR, Mogenson GJ (1990): Dopaminergic modulation of cholinergic responses in rat medial prefrontal cortex: An electrophysiological study. Brain Res 524:271-281

Yang CR, Seamans JS (1996): Dopamine D1 receptor actions in layer V-VI rat prefrontal cortex neurons in vitro: Modulation of dendritic-somatic signal integration. J Neurosci 16:1922-1935

Yang CR, Seamans JS, Gorelova N (1996a): Electrophysiological and morphological properties of layer V-VI principal pyramidal cells in rat prefrontal cortex in vitro. J Neurosci 16:1904-1921

Yang CR, Seamans JK, Gorelova N (1996b): Focal dendritic D1 receptor stimulation differentially modulates layer I-II and V-VI glutamate inputs to deep layer prefrontal cortical pyramidal neurons in vitro. Soc Neurosci $\mathrm{Ab}$ 22:1770

Yang CR, Seamans JK, Gorelova N (1997a): Mechanisms of dopamine modulation of GABAergic inputs to rat layer $\mathrm{V}-\mathrm{VI}$ pyramidal prefrontal cortical neurons in vitro. Soc Neurosci Abs 23:1771

Yang CR, Au-Young S, Shen H, Gorelova N (1997b): Layer V-VI prefrontal cortical outputs to the ventral tegmental area (VTA) and their firing modulation by VTA stimulation in vivo. Proceedings of the 33rd International 
Congress of Physiological Sciences (IUPS), St. Petersburg, Russia.

Yang CR, Seamans JK, Gorelova N (1998): Dopamine D1/5 receptor activation influences $\mathrm{N}$ - \& L-type $\mathrm{Ca}^{2+}$ channels to modulate dendritic $\mathrm{Ca}^{2+}$ potentials in pyramidal prefrontal cortex (PFC) neurons. Soc Neurosci Abs 24:854

Ye JH, Akaike N (1993): Calcium currents in pyramidal neurons acutely dissociated from the rat frontal cortex: A study by the nystatin perforated patch technique. Brain Res 606:111-117

Yuste R, Gutnick MJ, Saar D, Delaney K, Tank DW (1994): $\mathrm{Ca}^{2+}$ accumulations in dendrites of neocortical pyramidal neurons: An apical band and evidence for two functional compartments. Neuron 13:23-43
Yuste R, Tank DW (1996): Dendritic integration in mammalian neurons, a century after Cajal. Neuron 16:701-716

Zahrt J, Taylor JR, Mathew RG, Arnsten AFT (1997): Supranormal stimulation of D1 dopamine receptors in the rodent prefrontal cortex impairs spatial working memory performance. J Neurosci 17:8528-8535

Zhang P, Bunney BS, Shi W-X (1997): Electrophysiological characterization and effect of dopamine on visually identified nonpyramdal neurons in the prefrontal cortex. Soc Neurosci Abs 23:1212

Zhang X-F, Hu X-T, White FJ (1998): Whole-cell plasticity in cocaine withdrawal: Reduced sodium currents in nucleus accumbens neurons. J Neurosci 18:488-498 